\title{
Development of a Competitiveness Improvement Framework for Forensic Science Laboratories
}

\author{
Gloria Cuthbert Omari' ${ }^{1}$, Samwel Victor Manyele ${ }^{2}$, George Mwaluko ${ }^{1}$ \\ ${ }^{1}$ Department of Mechanical and Industrial Engineering, College of Engineering and Technology, University of Dar es \\ Salaam, Dar es Salaam, Tanzania \\ ${ }^{2}$ Government Chemist Laboratory Authority, Dar es Salaam, Tanzania \\ Email: omarigloria2@yahoo.com, mwalukogeorge@yahoo.com, gcla@gcla.go.tz,sammanyele@gma il.com
}

How to cite this paper: Omari, G.C., Manyele, S.V. and Mwaluko, G. (2019) Development of a Competitiveness Improvement Framework for Forensic Science Laboratories. Engineering, 11, 604-641. https://doi.org/10.4236/eng.2019.119042

Received: July 30, 2019

Accepted: September 20, 2019

Published: September 23, 2019

Copyright (@) 2019 by author(s) and Scientific Research Publishing Inc. This work is licensed under the Creative Commons Attribution International License (CC BY 4.0).

http://creativecommons.org/licenses/by/4.0/

\begin{abstract}
This study presents a methodology used in developing the competitiveness improvement framework (CIF) for laboratories, in particular, Forensic Science Laboratories (FSLs). The cyclic nature of FSL processes allowed data collection for the purpose of identification of factors affecting FSL performance (cause factors). Flow charts were used to represent mathematical formulations for cause factor measurements and quantification of the baseline data on turnaround time $(T A T)$, backlogs for case files $\left(B_{g}\right)$, turnaround time in the supply chain $\left(T_{s c}\right)$, and employee absenteeism $\left(A_{b}\right)$. By quantifying the cause factors in addition to academic development coefficient $\left(A_{d}\right)$ and complex longevity $\left(L_{c}\right)$ for FSL employees, it was possible to establish the organizational design features requiring improvements. The relevance of cause factors to FSL stakeholders and means of improvement and sustainability were established. A detailed road map towards CIF was presented using D-MAIC methodology. The rated cause factors based on challenges in the FSL business environment were subjected to Pareto analysis to prioritize the challenges in order to improve FSLs' competitiveness. The interrelationship between the three dimensions of competitiveness improvement (process, performance and planning) was presented in terms of the affected six cause factors. Also, the potential lean practices for improving competitiveness of FSL based on measured cause factors have been presented. This paper introduced methods and measures for improving operational competitiveness of laboratories. The CIF was finally presented in a form of a series of three flow charts summarizing all steps implemented in its development with inputs and cause factors involved.
\end{abstract}

\section{Keywords}

Competitiveness Improvement, Laboratory Process Variations,

Organizational Performance Factors, Pareto Analysis, Dimensions of 
Competitiveness, Wastes in Laboratory Processes, D-MAIC Methodology

\section{Introduction}

\subsection{Need for Developing the Competitiveness Improvement Framework for FSL}

The FSL consists of a series of connected processes beginning at SRO's office (when samples arrive) and ending at the same area where clients collect their analytical reports. In this study, the critical performance measures and cause factors were identified in order to develop the CIF. The contribution of this study to the global knowledge is mainly on forensic science laboratory management, which is a new research area involving competitiveness improvement. After establishing the baseline performance data, the study scope was extended to locating areas of improvement and the approach.

The current structure of forensic science services in Tanzania is defined using the basic processes shown in Figure 1 (starting from a crime scene to judgment at a court of law). The study area started from the time samples/exhibits are submitted to the laboratory to the time when a report is released.

The competitiveness scenario of FSL focuses on differentiation of services from its competitors and elimination of customer complaints due to delayed reports (extended TAT and backlogs). It was important to use the lean principles (LPs) based on essential characteristics and power to identify the non-value added activities (NVAs) [1].

\subsection{Baseline Data on Cause Factors Affecting Competitiveness in the FSL}

\subsubsection{Case-File Backlogs Challenge}

Case-file backlogs were identified as one of the cause factors affecting the competitiveness of the (FSL). Backlogs represent case-files that remain unprocessed or unreported within a selected time interval (year, week or month) which leads to increased customer complaints, rework, cost of analysis, degradation of biological samples, etc. Case-file backlogging was quantified in three consecutive years (Y2014 to Y2016) to study variations as case files are processed [2] [3] [4] [5]. Data were collected for the case-files received and case-files processed, difference of which gives case-files backlogged. The time interval for a case-file to be regarded as backlogged was one week, which can translate into backlogged case-files per month or year. A data collection tool was established and used for three laboratory disciplines (forensic chemistry, biology/DNA and toxicology).

The case-files received per week increased from 16.98 to 38.19 case-files between Y2014 and Y2016, respectively. It was observed that, case-files reported increased between Y2014 and Y2016 from 8.7 to 35.5 case files per week, respectively, leading to a decrease in backlogged case-files (from 10.7 to 2.1 case-files, 


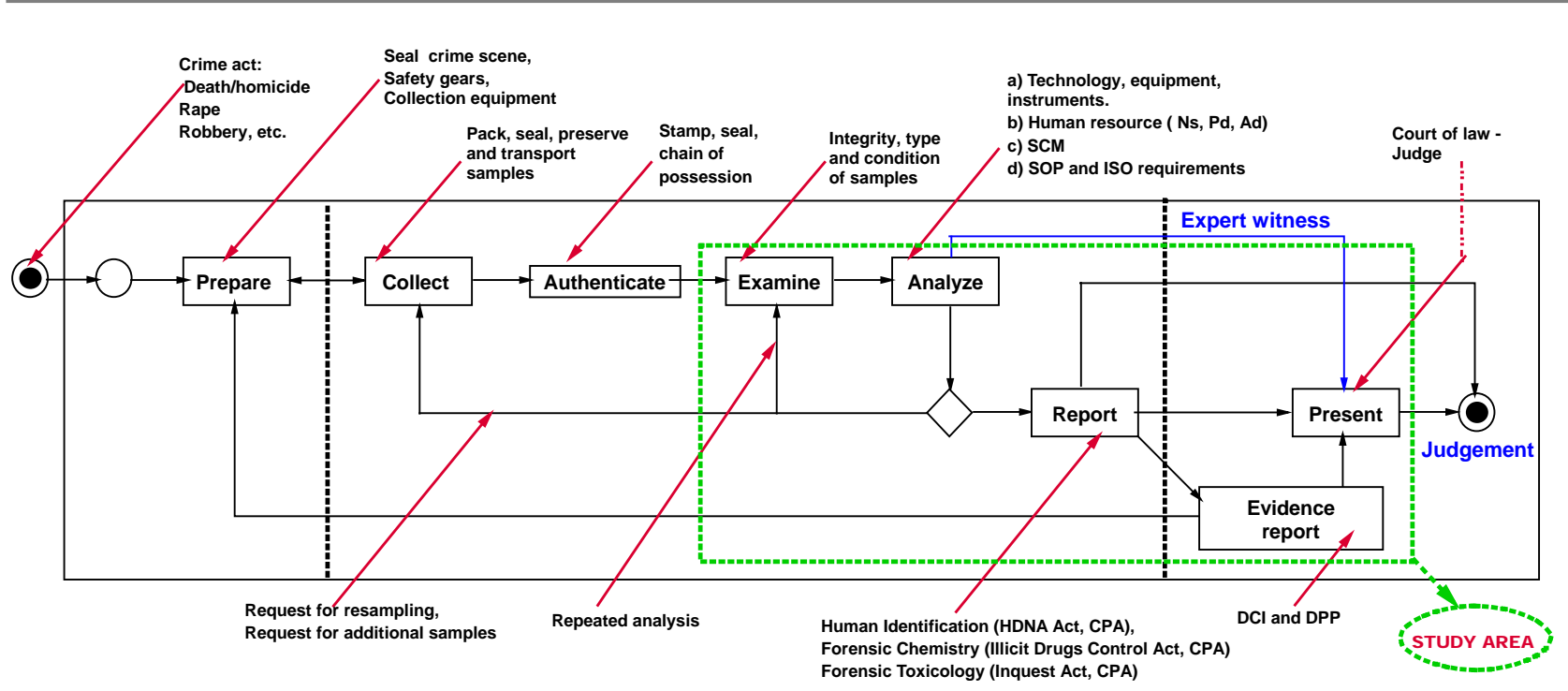

Figure 1. Process flow chart for forensic science services in Tanzania and the study area, identification.

respectively. The annual percentage of the case-files backlogged was highest for forensic toxicology (at 29.0\%), while the highest number of case-files backlogged per week was observed for forensic chemistry (1.0 case-file per week), followed by forensic biology/DNA (at 0.77 case-files per week) in Y2016.

The number of case-files backlogged per analyst per year was highest in Y2014 and dropped continuously towards Y2016, being comparably higher in forensic biology/DNA ( 8.0 case-files per analyst per year) and chemistry ( 7.4 case-files per analyst per year). The effect of case-file backlogging on FSL competitiveness can be minimized by continued management effort in backlog elimination [6] [7] [8].

\subsubsection{Extended Turnaround Time during Case-File and Sample Processing}

$T A T$ is the total time interval from when a request for laboratory analysis is received until when the results are collected by the client [9] [10]. The performance of the FSL is affected by extended TAT in the case-file and sample processing steps. This has not been subjected to intensive research, necessitating critical analysis [11] [12] [13] [14]. The total TAT was obtained as the sum of measured time interval for each work station, six of which were studied [15] [16]. Extended TAT leads not only to customer complaints, but also paves way for customers to seek for services from competitors, leading to lost competitive edge for the FSL. This study was conducted to establish the baseline data on TAT (between Y2014 and Y2015) to enable implementation of corrective actions [14]. Six case-file processing steps were identified for which starting and completion times were recorded in dates, giving $T A T$ values in days. The overall turnaround time (TTAT) was the highest for forensic biology/DNA compared to forensic chemistry and toxicology (137.7, 76.4 and 54.5 days on average, respectively). The laboratory analysis time $\left(T A T_{2}\right)$ was the longest of all six case-file processing steps (being 94.9, 31.8 and 10.4 days, for biology/DNA, toxicology 
and chemistry laboratories, respectively). The three major steps necessitating root-cause analysis and intervention to minimize $T A T$ were analysis turnaround time $\left(T A T_{2}\right)$, report collection time $\left(T A T_{6}\right)$ and report review time $\left(T A T_{4}\right)$. It was concluded that the causes for extended $T A T$ were within control by the FSL management, although financial and human resources were required to achieve the TAT reduction.

\subsubsection{Employee Absenteeism in the FSL and Its Impact on Competitiveness}

Absenteeism is a bigger problem affecting negatively the competitiveness of any laboratory [17] [18] [19]. A detailed analysis of the measured absenteeism data for employees in the FSL was conducted, using a sample size of 134 (78\%) employees out of 172 . While the availability of resources affects also the performance of the laboratory, absenteeism plays a vital role, worth exploring [20] [21] [22] [23] [24]. The factors assumed to affect absenteeism included differences in gender, departments/units, periods of the year, skill-levels and professions (chemists, technologists and accountants). The data were collected throughout a calendar year, using a biometric system infrastructure incorporating fingerprint capturing device, IP camera, database server and software (Bio Star Version 1.62) [25]. The absenteeism ratio based on hours, $A_{b h}$, was observed to be the most appropriate parameter [25]. The lowest values of $A_{b h}$ (at $0.82 \%$ annual average) were observed in the business development department (BDD), with highest in PQSD at 26.91\%. Female employees show higher $A_{b h}$ (at 17.54\%) and lower $A_{b d}$ (at 20.36\%) than male employees (at $12.93 \%$ and $20.36 \%$, respectively), while accountants show lowest absenteeism (at $-4.94 \%$ ) compared to other professions ( $12.58 \%$ and $36.58 \%$ for chemists and technologists, respectively). Employees in professional level had highest absence rate (24.0\%) compared to skilled (13.6\%), semi-skilled (12.7\%) and unskilled employees (9.5\%). Most working hours were lost during September-December compared to the rest of the year. The results reveal higher employee absenteeism in the FSL affecting its overall performance as lost productivity [26] [27] [28].

\subsubsection{Employee Longevity and Academic Development}

A detailed analysis of academic development index and longevity among laboratory employees was conducted aimed at improving organizational performance [29]-[35]. Data were collected from human resource database involving 171 (88\%) employees out of 195 . New mathematical formulations were developed for academic development index $\left(A_{d}\right)$, simple longevity $\left(L_{s}\right)$ and complex longevity $\left(L_{c}\right)$. The values of $A_{\phi} L_{s}$ and $L_{c}$ were compared for different units and departments including zonal laboratories between Y2014 and Y2016. Both total and average values of $L_{s}, L_{c}$ and $A_{d}$ indicated an imbalance in the distribution of staff in different laboratories, necessitating re-allocation to improve performance. The employment trend analysis indicated that the work force has been diversified from Y2004 to Y2016 leading to improved management of finance, procurement and human resource in the laboratory. As a result of a training pro- 
gram, the percent of staff with MSc has been increasing from about 3.5\% in Y2004 to 9\% in Y2015. Results show that a balanced staff distribution based on $L_{c}$ and $A_{d}$ is inevitable for improved performance. It was concluded that the new indices $\left(A_{d}\right.$ and $\left.L_{c}\right)$ are important tools towards development of the workforce and competitiveness of any laboratory as they lead to human performance improvement (HPI) [36] [37].

\subsubsection{Turnaround Time for Supply Chain Management Processes}

The Supply Cycle Time (SCT) denoted as $T_{s c}$ depends on all factors that affect the turnaround times across its key components (the user, supplier, tender board, the procurement management unit performance). Baseline study revealed wide variations in $T_{s c}$ giving a mean of 105.6 days, which is extended. Reduction in $T_{s c}$ must involve the FSL management and all key players in the SCM processes. However, the reduction of SCT by elimination of wastes in the processes is difficult as most of the SCM steps in between are pre-requisite in the said process and the steps are mandatory. Thus, step by step reduction in the $T_{s c}$ is required. Lack of knowledge on procurement processes by staff in the user departments is another challenge to the FSL competitiveness. The $T_{s c}$ is also extended due to the fact that most of the laboratory suppliers involve a relationship with third party vendors, which implies a complex relationship with the FSL.

\section{Literature Review}

\subsection{Impact of Process Variables on FSL Competitiveness}

The pillars of the FSL competitiveness include processes and organizational design. All these areas have been studied in details, before developing the CIF. Turnaround time analysis was accomplished by identifying action points to be assessed [9] [38] [39], followed by detailed data collection. Moreover, the backlogged case-files, $N_{c b}$, were also repeatedly captured at different action points by determining the number of case-files received and reported [5].

The laboratory turnaround time can also be defined differently according to the test type or analysis requested. The "total testing cycle" describes TAT as a syndicate of eight stages: collection, identification, transport, preparation, analysis, reporting, interpretation, and action [40].

Supply chain management (SCM) is an integrative philosophy to manage the total flow of a distribution channel from supplier to the ultimate user [41] [42]. In this study, SCM analysis comprised of: determination of the TAT components in SCM; determination of procurement performance measurement system; interaction between the user, procurement management unit (PMU), accounts and supplier, and determination of the key metrics for supply chain management (financial and other metrics).

Organizational design analysis included case-file flow steps, supply chain management and human resources, and the actual human resource management (HRM). HRM involves forecasting and placement, staff experience and longevi- 
ty, academic and professional development, staff absenteeism, staff responsibilities and interactions [25] [43] [44].

\subsection{Resource-Based Competitiveness}

Researchers have advanced various methods for improving performance of laboratories including competitiveness, for example, a resource-based method [45] [46]. The term resource is meant anything which could be thought of as strength of a laboratory as an organization. According to this broad definition, resources can be tangible or intangible. In this case, organizations perform poorly because either they possess resources that are not in demand, own resources that are not scarce or do not own such resources [46] [47]. Improving performance of a laboratory requires understanding the core processes and factors hindering these processes. Intervention under this method would comprise of searching for resources that are in demand, scarce and appropriated by the organization, such as working areas, machinery, skilled and well developed staff, motivated staff, etc. Improving performance should adopt an industry-based method, which relies on the principles that laboratory success is based on its ability to harness opportunities and tame threats that exist in the business environment [48] [49].

\subsection{Effect of Extended Turnaround Time in Supply Chain Management on FSL Competitiveness}

Supply chain management (SCM), is among the factors affecting FSL competitiveness. In this study, supplier-laboratory interactions have been assessed based on $T_{s c}$ and financial metrics, etc. In FSL, the role and importance of the supply chain is mainly understood as evidence supply chain or the storage of evidence at the FSL. In this study, however, SCM focuses on material and services flow from suppliers. One of the methods which can be used to assess the key performance of supply chain management in the laboratory setting is consideration of issues affecting supply chain [50]. However, there is a need of having supply chain operators responsible for managing inventory flow to ensure that the goods arrive at the right place at exactly the right time, that is, the procurement management unit (PMU).

Supply chain performance measures (SCPM) serve as indicators of how well the supply chain system is functioning. Measuring SCP can facilitate a greater understanding of the supply chain and allow improving its overall performance [51] [52]. Different perspectives of SCPM are cost and non-cost perspective, strategic, tactical or operational focus [53] business process perspective and financial perspective [54]. In this study, the focus was on the challenges especially the turnaround time at every stage of product supply consideration and hence the total turnaround time, $T_{s c}$. The focus of SCM was the availability of services, consumables, reagents, chemicals, instruments or equipment for all laboratory settings. 


\subsection{Models for Improving Organizational Competitiveness}

Competitiveness is a multidimensional concept, observed from different levels: national and organizational or firm level. Competitiveness means involvement in a business opposition for markets, in this study used to describe economic strength of entity laboratory with respect to its competitors [55]. Laboratory or firm-level competitiveness is defined as the capacity of the laboratory to design, produce and or sell its products or services superior to those offered by competitors, considering the price and non-price qualities.

Researchers suggest different framework designs for competitiveness. While others suggest a framework with three folds: performance, potential, and the management processes, others suggest a framework that involves a combination of assets and processes, where assets are either inherited (natural resources) or created (infrastructure) and processes transform assets to achieve economic gains from sales to customers [56]. Other authors present an approach which emphasizes the role of factors internal to the laboratories such as strategy, structures, competencies, capabilities to innovate, and other tangible and intangible resources for their competitive success [57] [58]. In order to provide customers with a greater value of satisfaction than their respective competitors, laboratories must be operationally efficient, cost effective, and quality conscious [59].

Competitiveness improvement process seeks to identify the important factors and performance of core processes including the human resource processes, operations management processes (that is, laboratory processes based on case-file management and supply chain management) and planning or strategic management processes. Balancing the core processes will enhance the ability of laboratory to compete more effectively. Researchers view sources of competitiveness as those assets within the laboratory organization that provide advantage which can be tangible or intangible [60].

Business design for FSL, therefore, has two principal requirements: sustaining casework productivities in a timely and efficient manner, whilst adhering to quality standards and the timelines of the investigatory and judicial processes. The design involves also developing and executing major programs of infrastructure investment and process re-engineering. Competitiveness is the ability of a laboratory or country to offer services and products that meet the quality standards of the local and global markets at prices that are competitive and provide adequate returns on resources employed [46] [61]. Competitiveness of a laboratory is measured in terms of quality of service, level of productivity, quality of human resource, price, and ability to innovate [31] [32] [35] [62] [63].

Though several performance improvement methods have been proposed by scholars, yet they possess inherent deficiencies. Most literature discusses performance factors in singular. Therefore, in this study, competitiveness is discussed as multidirectional and multifactor concept observed at laboratory or firm-level. The multi-factors considered include the strategies of reducing backlogs, turnaround time and fewer customer complaints. The framework devel- 
oped covers also multidimensional aspects of organizations namely, organizational processes, design, culture and politics [64]. The need to consider the environment is also taken into account in particular the stakeholder demand of services, and challenges in the laboratory business environment [48].

\section{Methodology}

\subsection{Utilizing the Cyclic Nature of the FSL Processes}

(CIF) applies repetitive business processes such as the case flow management (CFM) assessed thoroughly in this research. In the FSL model setup, each case-file passes through several action points and complete processing is achieved before passing to another point. Whenever any action is completed time taken was noted while, if the case files are not completed in seven days, the case file is regarded as back logged. When another request for analysis of samples arrive, the same process is repeated at varying performance, measured using $T A T$, case-file backlogs $\left(B_{g}\right)$, coupled with assigning staff of different traits $\left(A_{\phi} L_{c}\right.$ and $\left.A_{b}\right)$, leading to a dynamic cyclic process of different characteristics. Figure 2 shows the decision diagram for conducting CIF analysis by observing designated events at different action points. Table 1 summarizes the parameters or cause factors assessed after capturing data in this study.

In forensic science laboratory, the repeating business takes place within the organization design or in the processes taking place within the laboratories. All the six parameters, or cause factors for FSL competiveness can be tracked in a repeating mode using the case-files as a unit of measure for laboratory issues $\left(B_{g}\right.$, $T A T)$, purchase order processing $\left(T_{s c}\right)$ and absence/presence of staff with different traits $\left(A_{\phi} L_{c}\right)$ based on assignment case files (number of case files per analyst per year) and biometric database on daily basis $\left(A_{b}\right)$. However, intervals among action points differ from one case-file to another which was measured leading to wide data volume for $T A T$ and $B_{g}$. The processing time was also different for each purchase order, leading to data on $T_{s c}$

\subsection{Capturing Variations in the Total Turnaround Time and Backlogs during Case-File Management}

Variations were identified in the turnaround time (TAT) for sample analysis.

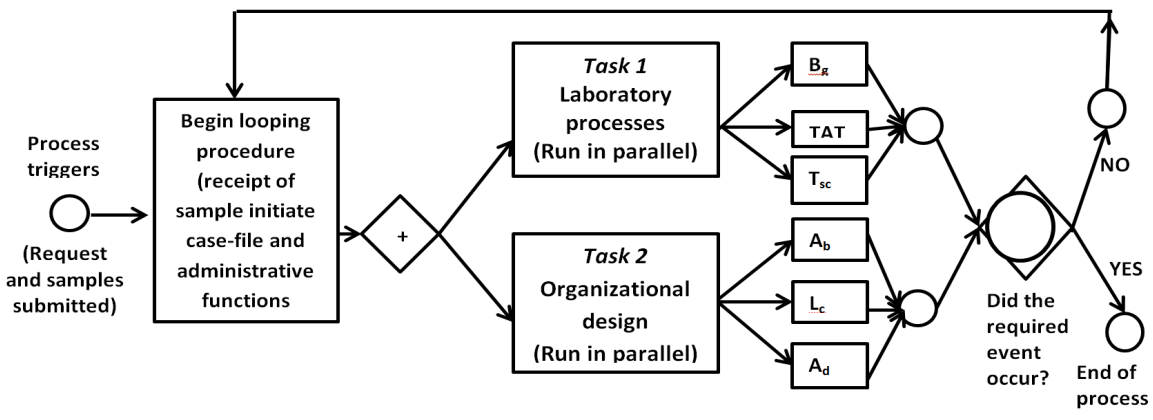

Figure 2. Repeating business process map for case-file management in the FSL. 
Table 1. Cyclic nature of the FSL processes and methods adopted for studying variations in the FSL processes.

\begin{tabular}{|c|c|c|}
\hline Cause factor & Nature of variations & Method used to study variations \\
\hline$B_{g}$ & $\begin{array}{l}\text { For one calendar year, all case files received } \\
N_{c r} \text { undergoes processing in the same } \\
\text { environment, leading to processed and } \\
\text { reported case file, } N_{c p} \text {. }\end{array}$ & $\begin{array}{l}\text { Case-file backlogs were studied as function of time for case-files received and } \\
\text { processed in Y2014, Y2015 and Y2016, as a function of time for all } 52 \text { weeks of the } \\
\text { calendar years, and also as a function of laboratory disciplines within the FSL. }\end{array}$ \\
\hline$T_{s c}$ & $\begin{array}{l}\text { All purchase orders are initiated and } \\
\text { completed leading to a spread in the } \\
\text { values of } T_{s c}\end{array}$ & $\begin{array}{l}\text { Turnaround time between different action points within the FSL } \\
T A T \text { for internal and external SCM processes during order processing. }\end{array}$ \\
\hline$T A T$ & $\begin{array}{l}\text { All case files go through the process from } \\
\text { receiving to collection. }\end{array}$ & $\begin{array}{l}\text { TAT studied as function of time for case-files received and processed in Y2014 and } \\
\text { Y2015, and also in different laboratory units. }\end{array}$ \\
\hline$A_{b}$ & $\begin{array}{l}\text { All staff report to work daily, punch in and } \\
\text { punch out leaving traces of absence or } \\
\text { presence which can be measured. }\end{array}$ & $\begin{array}{l}\text { Absenteeism studied as a function of time for three months periods of Y2016. } \\
\text { The studied covered factors affecting absenteeism such as departmental setups, zonal } \\
\text { laboratories, skill levels, professions and gender. }\end{array}$ \\
\hline$A_{d}$ & $\begin{array}{l}\text { All staff have own academic development } \\
\text { profile. }\end{array}$ & Variations of $A_{d}$ with time (Y2014, Y2016) for individual staff and by departments. \\
\hline$L_{c}$ & $\begin{array}{l}\text { All staff have measurable complex longevity } \\
\text { within the FSL. }\end{array}$ & $\begin{array}{l}\text { Variations of } L_{\mathcal{O}} L_{c t} \text { and } L_{s t} \text { with time (Y2014, Y2016) for individual staff and } \\
\text { laboratory units. }\end{array}$ \\
\hline
\end{tabular}

The identified six components of the total turnaround time (TTAT) were also identified, which in turn vary from one case-file to another [14]. Each time interval between action points was determined as the difference between receiving and completion of processing time in the same action points. The initial and final times were recorded in dates giving $T A T$ values in days, as shown in Figure 3. For simplicity, during $T A T$ analysis, some of the time intervals were combined to give one delay reducing the number of time intervals or action points from 20 to 6. Meanwhile, some actions could proceed in parallel (where the reference date remains the same).

Based in Figure 3, the number of backlogged case-files was determined for each laboratory discipline, by comparing case-files in and case-files out, in a specified time interval, say 7 days [5] [14].

\subsection{Capturing Variations in the SCM Performance Measures}

Turnaround time variations were also captured in the supply chain management. The supply chain cycle time, denoted as $T_{s c}$ which measures the total time required to complete the order. The methodology used to establish the $T_{s c}$ is complex due to wide involvement of staff and stakeholders, as well as large number of steps or action points. Repeating cycles in the form of orders were assessed and characterized as purchase orders were initiated and processed. For simplicity, the complex interactions among different SCM parameters were grouped together and the time between the order request and final payments were recorded. For further investigation on the effect of external environment on FSL competitiveness, the analysis was conducted separately for cycle times covering internal and external operations on purchase orders. Given the total 


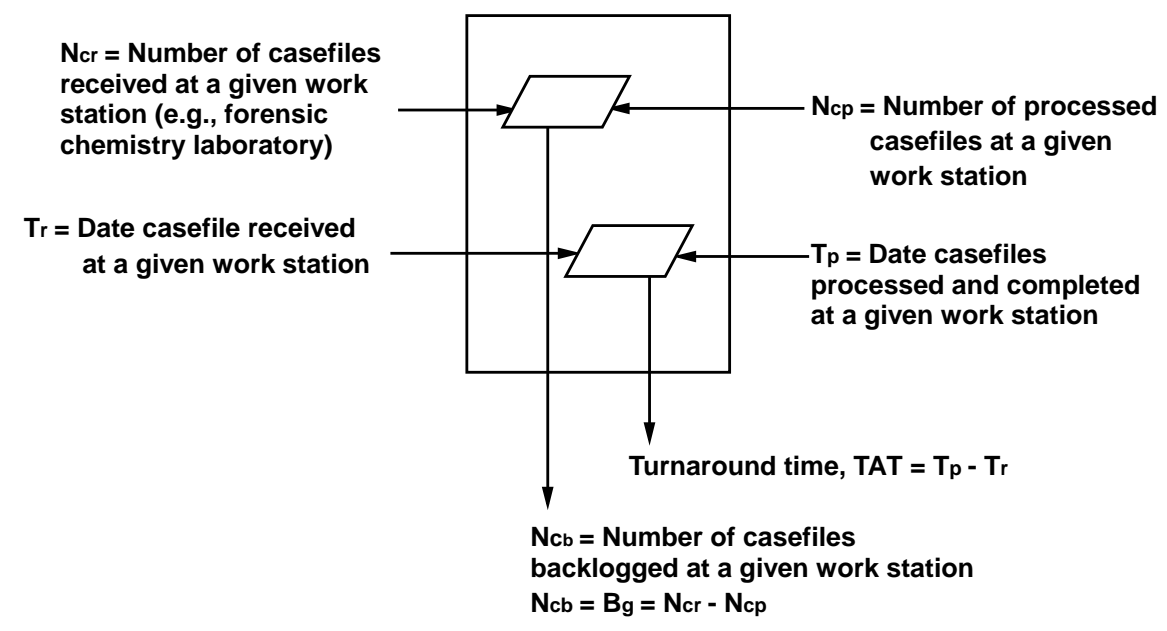

Figure 3. Capturing the repetitions and differences in $T A T$ and backlogs for case-files at each work station.

number of orders in the period studied, $N_{t o}$, all the order processes falls in the cyclic nature and repetition, which fits well into the development of the CIF.

The supply cycle time, $T_{s c}$ including payments acknowledgement, was determined as difference between date payments are made and acknowledged, $T_{p a}$ and the date purchase order is requested by the user department, $T_{o s}$. Table 2 summarizes the time variations by years studied and purchase order sampling details for determination of $T_{s c}$ Each purchase order processing undergoes the same cycle, based on which, variations in the cycle times were captured.

\subsection{Variations in Staff Absenteeism}

Measurements of absenteeism ratio, $A_{b}$, started with collecting data for individual employee on daily basis using the biometric system, from which, the ratio was expressed in terms of hours or days absent. For 192 staff logged into the system, this is a complex data set to manage [25]. Thus, the data was grouped into three time intervals (4 months), departments, units, gender, professions and skill levels to characterize and compare the average values. The determination of $A_{b}$ is characterized by long time interval ( 3 months in this case), data screening to eliminate staff with special absence like study leave, maternity leave or sick leave, wrong data entry and errors, which reduces the sample size. The mathematical formulations implemented for absenteeism analysis can be summarized using a flow chart as shown in Figure 4, which shows two different outcomes of absenteeism data analysis, that is, day-based and hour-based absenteeism ( $A_{b h}$ and $A_{b c}$ respectively) [25].

\subsection{Variations in the Staff Academic Development}

Another variation within the laboratory was identified in the staff academic development, experience and longevity which originate from individual employee data. The cyclic nature on this case stems from the fact that during employment 
Table 2. Sampling details for case files used for supply cycle time analysis.

\begin{tabular}{cccc}
\hline Financial year & $\begin{array}{c}\text { Number of sampled } \\
\text { purchase orders }\end{array}$ & $\begin{array}{c}\text { Number of purchase order } \\
\text { used to determine } T_{s c}\end{array}$ & $\begin{array}{c}\text { Percent of total purchase } \\
\text { orders (\%) }\end{array}$ \\
\hline $2012 / 13$ & 156 & 44 & $28.2 \%$ \\
$2013 / 14$ & 213 & 44 & $20.6 \%$ \\
$2014 / 15$ & 215 & 44 & $20.5 \%$ \\
$2015 / 16$ & 141 & 44 & $31.2 \%$ \\
\hline
\end{tabular}

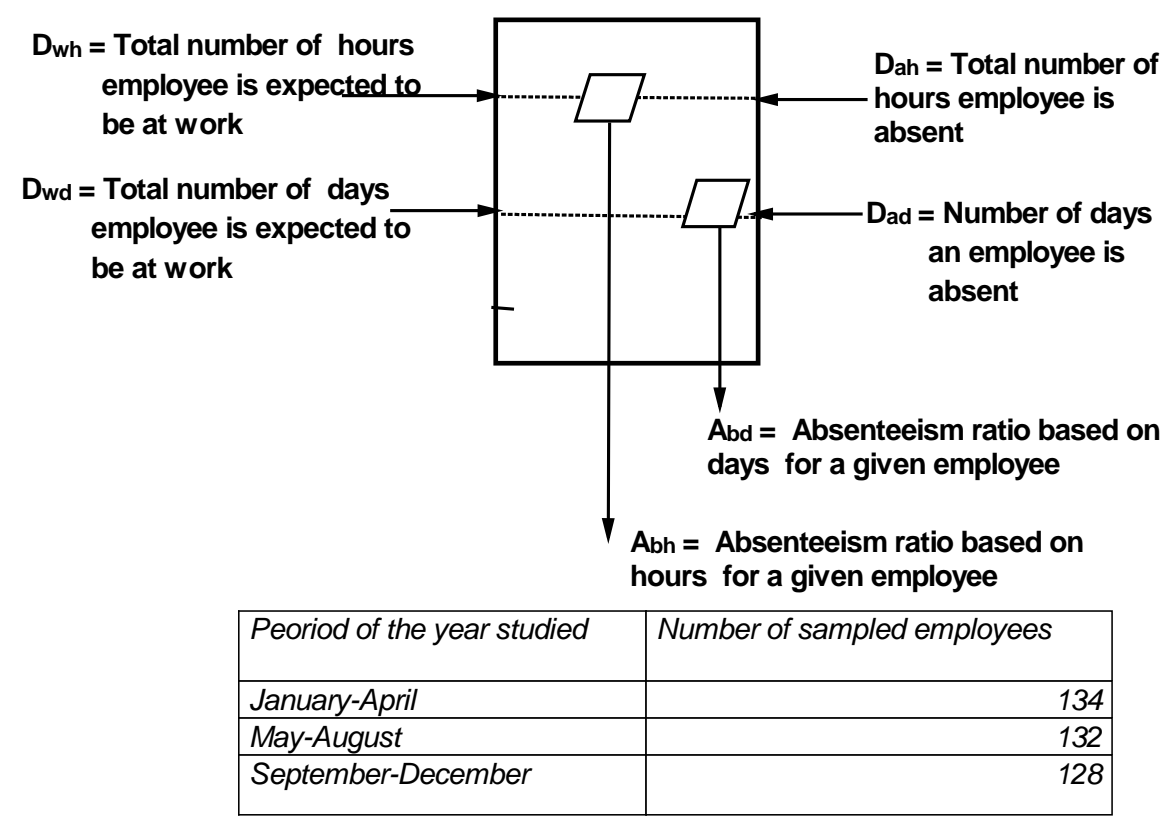

Figure 4. Flow chart for determination of employee absenteeism ratios $A_{b h}$ and $A_{b d}$ (based on 192 total employees).

and working life, each individual staff is subjected to academic development and longevity, data of which was captured not only once but at different times (Y2014 and Y2016) for comparison [44]. Successful management of any laboratory requires a great sense of self-awareness, commitment or engagement and the presence of the staff in the processes where academic development index, $A_{\phi}$ and complex longevity, $L_{\mathcal{O}}$ play a vital role in performance and hence, competitiveness of the whole FSL as an organization. The parameters used to assess staff development (academic and professional development) are summarized in Figure 5. These variations arise among employees and also change with time for individual employees, specific FSL units or departments (total complex longevity or academic development index), which were used to develop the CIF. Thus variations in employee trails were captured as time possess while individual employee data offers another variation analysis opportunity by comparing individual staff, laboratory discipline, or zonal setting. The sample size (number of employees in each period) used to study variations in the academic development and longevity is also summarized in Figure 5. 


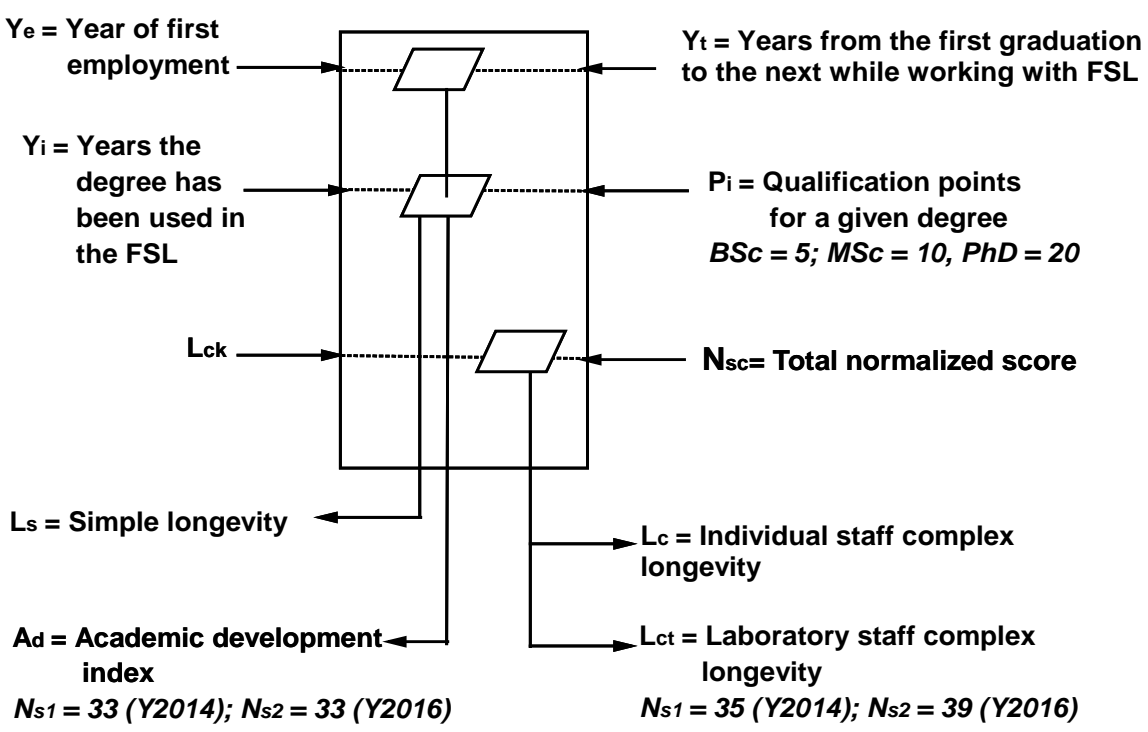

Figure 5. Determination of academic development coefficient, $A_{\phi}$ and complex longevity, $L_{c}$

\subsection{Methodology for Implementation of Pareto Analysis}

Given the six cause factors measured and implemented in the CIF development process, each factor was assessed on its relationship with: a) challenges in the FSL business environment and b) applicability of the lean practices for improving FSL competitiveness. The business environment challenges studies were 8 while the lean practices for CIF were 5 , the so called variants. Let $N_{v}=$ number of variants, that is, number of challenges in the business environment or number of lean practices ( $N_{v}=8$ and 5 respectively), and $N_{c f}=$ number of cause factors measured and assessed for CIF development, that is, $N_{c f}=6$. Then, using a scoring system of $N_{s}=1,2$ or 3 for low, medium and high connection between the cause factors and the challenges or practices respectively, the total score, $S_{\text {too }}$ for a given variant, was established based on Equation (1):

$$
S_{\text {tot }}=\sum_{i=1}^{N_{c f}} N_{s, i}
$$

The total score values for each variant, were then used to establish the percentage frequency distribution, using Equation (2).

$$
F_{d}=\frac{S_{t o k, k}}{\sum_{k=1}^{N_{v}} S_{t o t, k}}
$$

Finally, Pareto analysis was conducted by analyzing the $F_{d}$ values.

\section{Results and Discussion}

\subsection{Summary of Variations Captured in the Laboratory Processes}

\subsubsection{Variations in the Turnaround Time}

Based on TAT analysis, the performance of FSL disciplines shows strong variations between Y2014 and Y2015 as presented in Figure 6. For forensic chemistry, 


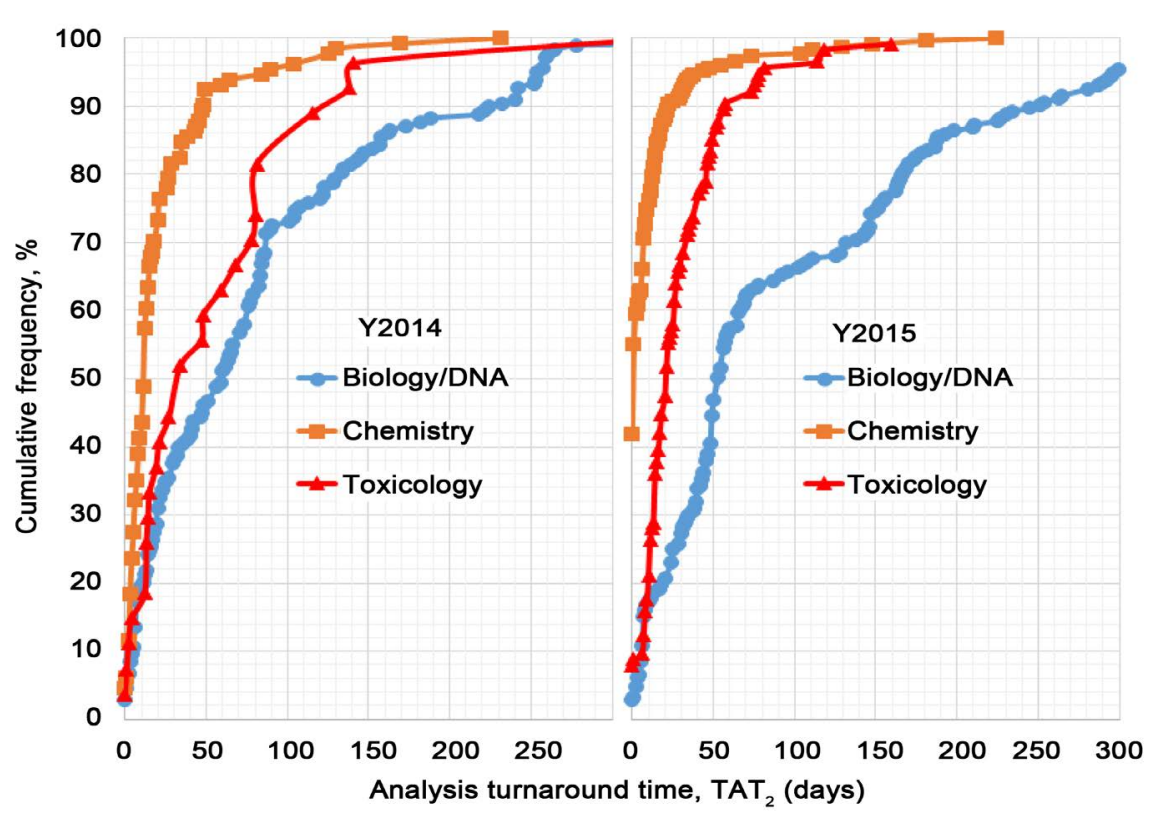

Figure 6. CDFs of laboratories analysis turnaround time data for different laboratory disciplines in Y2014 and Y2015.

the number of case-files completed within one day of submission increased from $2 \%$ in Y2014 to 45\% in Y2015. For biology/DNA, on the other hand, an opposite scenario was observed, as the performance decreased leading to very few case files completed in a given time of 50 days from $50 \%$ to only $35 \%$ of case files. For forensic toxicology, improved performance was observed, for instance, at a given $T A T_{2}$ of 50 days, $60 \%$ of case files were completed in Y2014 which increased to $85 \%$ in Y2015. Cases where performance dropped require intervention if the FSL is to remain at its competitive edge.

\subsubsection{Variations in the Backlogged Case-Files}

According to Figure 7, variations in the laboratory performance with time for each discipline are obvious. The laboratory backlog data was assessed for each calendar year, from Y2014 to year Y2016. Figure 7 shows the cumulative distribution for $B_{g}$ data for 52 weeks in each year. By drawing a vertical line at $B_{g}=10$, using the collected data in three consecutive years, it is evident for DNA laboratory that the backlogs increased between Y2014 and Y2015 and decreased between Y2015 and Y2016. For forensic toxicology, backlogs increased between Y2014 and Y2015 while in forensic chemistry, backlogs decreased. Thus, variations in cause factors have been captured using data collection tools applied to the cyclic nature of the processes, allowing for identification of root causes and taking action to improve and sustain.

\subsection{Harnessing Variations in Cause Factors for Competitiveness Improvement}

One of the first steps towards FSL competitiveness improvement was to establish where the FSL stands among other organizations, that is, bench marking. The six 

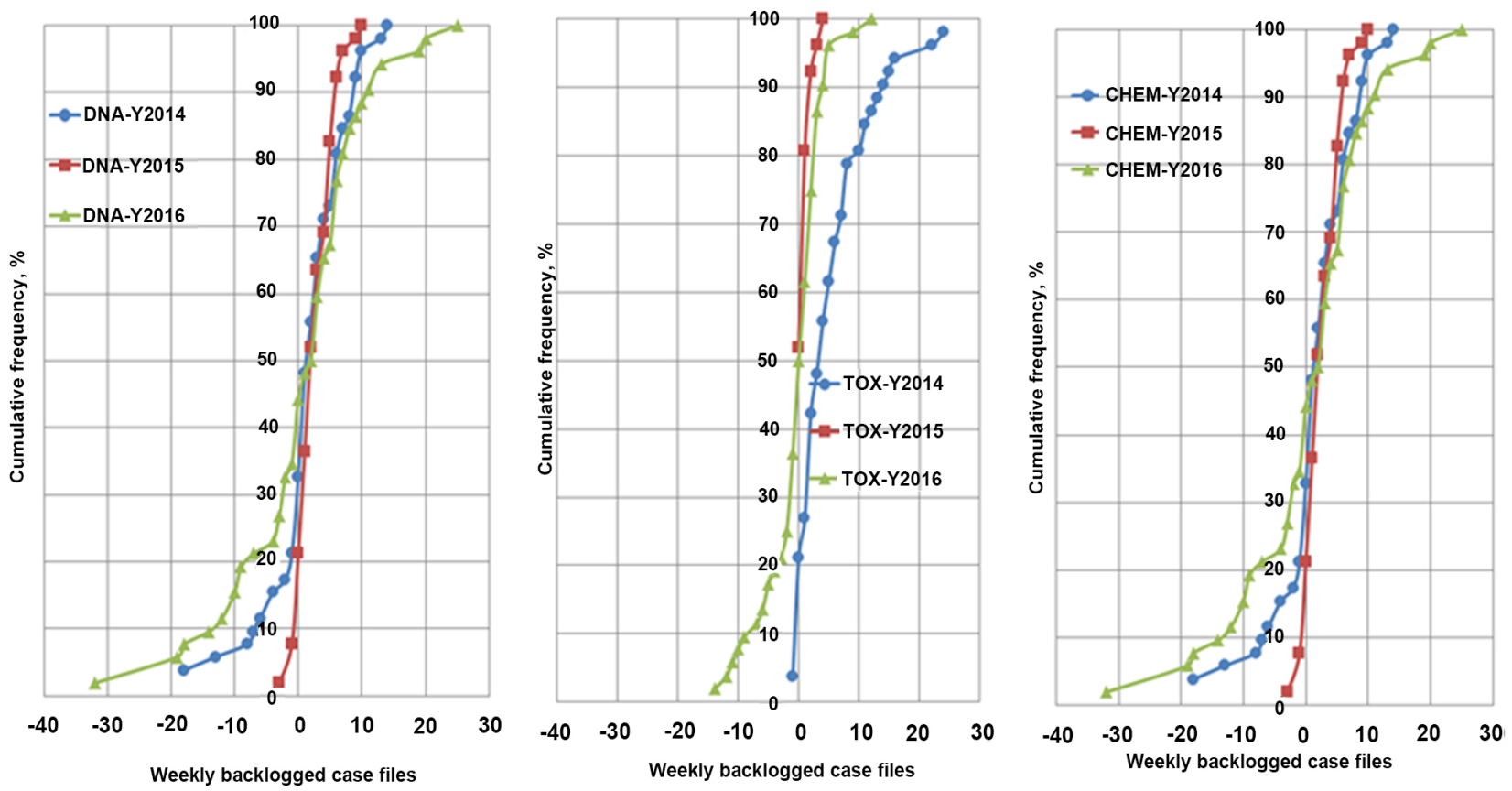

Figure 7. Variations in the weekly backlogs for three consecutive years.

parameters or cause factors affecting competitiveness were studied in details and quantified between Y2014 and Y2016 so that improvements and sustainability can be measured in the next few years or later. This study is thus used as a definitive guide on what needs to be improved. Table 3 gives what is needed to improve based on the pre-determined performance factors and how to approach the improvements. In details, gives the key steps applicable to each cause factor starting from relevance of each factor to FSL, stakeholders and baseline or current status are given. Means of improving and sustaining competitiveness via these cause factors are also presented in Table 3. Finally, future plans for sustaining competitiveness are also summarized.

Not shown in Table 1 are the responsible directors, managers or departments and units towards sustainability of the competitiveness improvement methods identified which can be done internally, as it depends on the organizational structure of the laboratory. With six cause factors identified, improvement of competitiveness is not a minor task since requirements span into many directions and above all, time consuming and costs money. Maintaining the competiveness is a difficult task because of many factors that influence the FSL and the market or clients, some of which are not controllable by FSL management (e.g. components of SCM played by suppliers) necessitating efforts in backstopping. Factors like technological advancement or lack of specialized equipment could put the laboratory out of competitive advantage. If improvements are made across the six cause factors, the resulting competiveness improvement will be achieved through reduced backlogged case-files, reduced TAT and improved QMS. 
Table 3. The relevance of cause factors of the FSL performance towards competitive improvement.

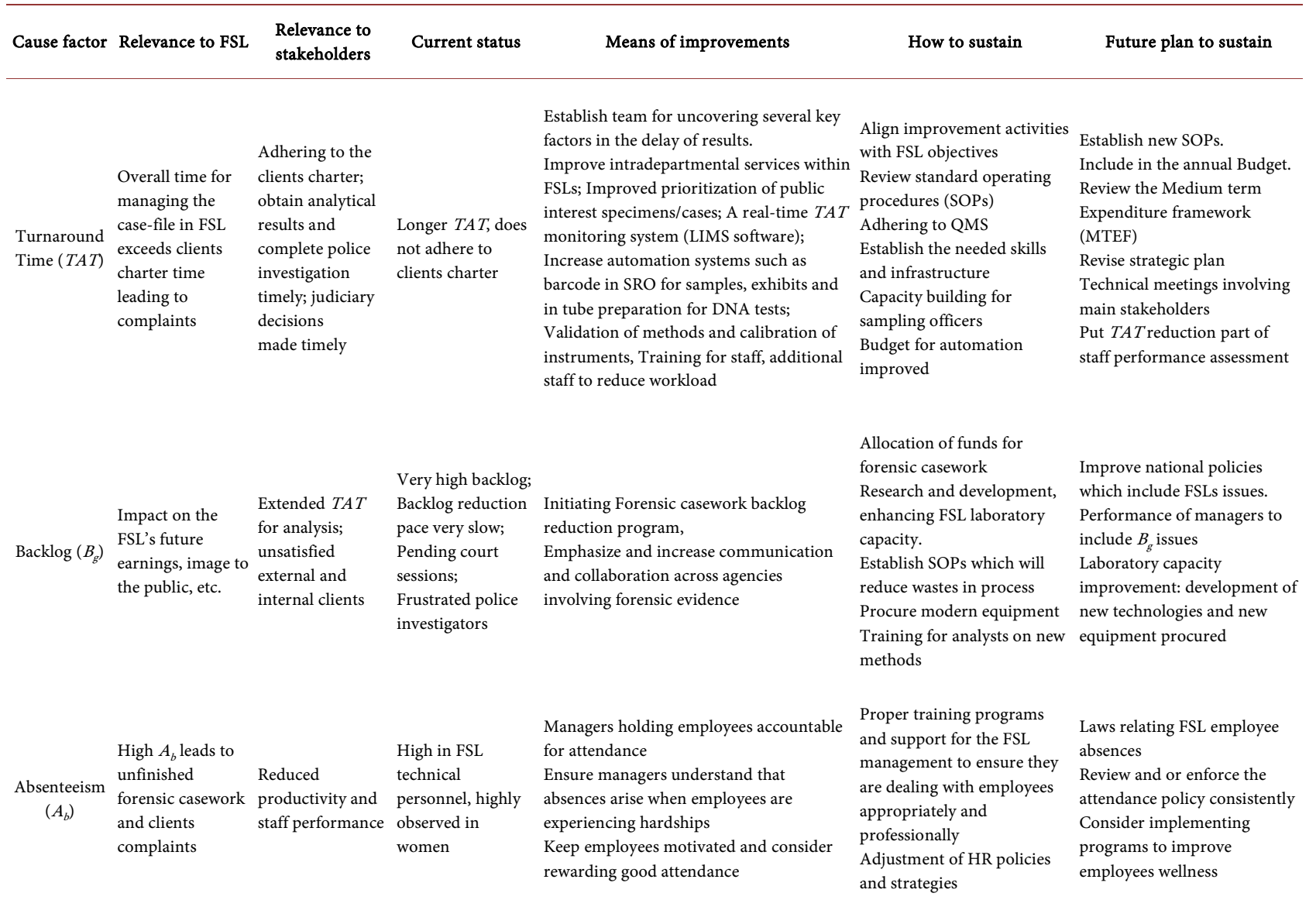

Leads to increased scientific capacity, managerial and leadership skills;

Academic Improved

$\left(A_{d}\right)$

decision making in differen situations; Improved innovation

Staff experience and long stay in FSL;

Longevity Enhancing the

$\left(L_{c}\right) \quad$ quality of output; Part of staff broad knowledge, expertise
Increased credibility of and improved report scrutiny Court session performance improved

Increased

competencies and Few staff with high ability to perform $L_{c}$ in FSL; Lower $L_{c}$ analytical work to values in general the client's needs than support cadres due to lack of specialized training in the region writing.

Training short course data interpretation on complex genetic profiling Training on legislations
Keep track of $A_{d}$ values on annual basis to study changes and taking action Identify gaps and redundancies in labs and move staff

\section{capacity buildin}

Consider the factor(s) which motivate the FSL staff to continue working in FSL

Policy changes by valuing their work and input/output
Develop succession and competence plan for the different disciplines
Improve payment package; Retirement benefits/prizes; initiate long stay prizes

\section{Supply Chain $T_{s c}$ measures Management timeliness of \\ Time $(T)$ supplies and ervices to FSL}

Suppliers of goods Identify specific targets for supply chain and services are enhancements such as reduced $T_{s \dot{c}}$ also cause delays Shipping from manufacturers directly;

Tracking of and complaints on Train all FSL staff on supply chain procured supplies and complaints on Train all FSL
to provide quality internal process management; and timely laboratory services delayed; cycle Communicate with all staff involved in the completion involve SCM on: what, why, who and when, so as performance of to avoid surprises.

staff within FSL Assure clarity of roles and responsibilities and external agents for all SCM players
Develop new SOPs on SCM; Establish supply chain metrics related to FSL Develop software tailored for competitiveness; Collect and manage relevant LIMS, etc.

information; Appropriate allocation of Analyze to identify funds for procurement bottlenecks

Establish supplier list for FSL 


\subsection{Competitiveness Improvement by Managing the Dimensions}

\subsubsection{Dimensions of the FSL Competitiveness}

The competitiveness improvement framework involves individual staff, product (laboratory reports) and FSL services (receiving/processing exhibits, expert witness and training for sampling officers). Single measures of competitiveness (e.g. finance, SCM, etc.), do not capture all the elements of the research issue, it was necessary to examine performance, potential and management processes (shown in Figure 8), in order to evaluate critically the changes or level of competiveness and interrelationship. The Venn diagram in Figure 8 shows the interrelationship between the competitiveness dimensions based on the cause factors measured and analyzed in this study.

\subsubsection{Competitiveness Improvement by Managing Performance in the Laboratory}

Under this component, the study measured the status of $A_{d} L_{c}$ and $A_{b}$ which are related to staff capability or tools to enable them push the organization towards competitive advantage, for the FSL to improve its performance. Managing the performance in FSL should be an ongoing communication process conducted which is carried out between the supervisors and the employees throughout the year. A system of managing the performance comprises of activities such as development of job descriptions within the different FSL disciplines and employee performance plans which includes the key result areas (KRAs) and performance indicators with respect to the cause factors: $A_{d} T A T, T_{s c}$ and $B_{g}$. Placement and staffing of the appropriate staff and providing continuous training and response during the period of delivery of performance is essential in performance management.

A performance management process sets the stage for fulfilling distinctions by supporting the FSL staff undertaking with the FSL mission and. The CIF is designed with the objective of improving both individual and FSL performance by identifying performance requirements with respect to the cause factors, providing regular feedback and assisting the FSL's employees in their career development. It is also aimed at building a high performance culture for both individuals and the FSL management team so that they jointly take the responsibility of

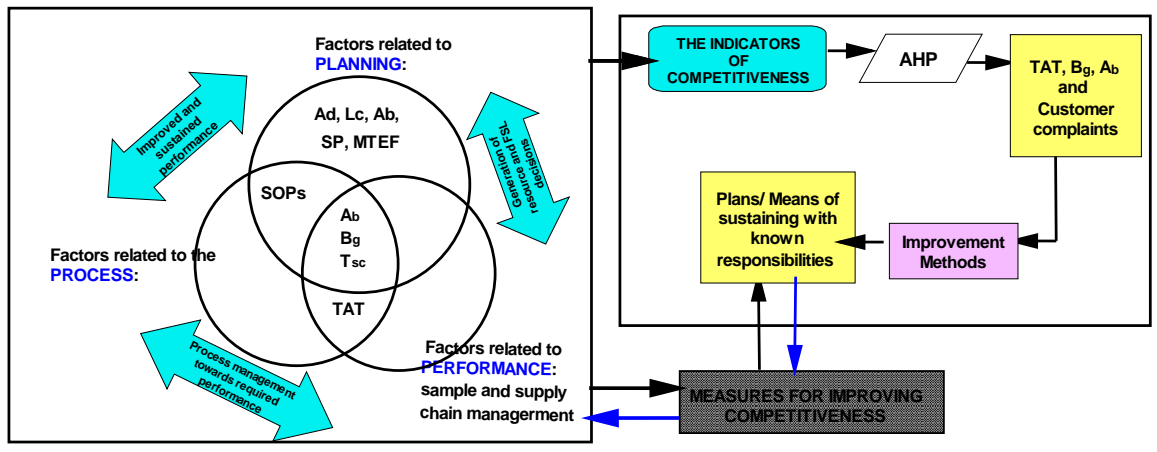

Figure 8. Interrelationship between the dimensions of FSLs competitiveness. 
improving the business processes on a continuous basis and at the same time raises the competence bar by upgrading their own skills within a leadership framework.

The sole purpose of a performance management system for a given laboratory is to assess and ensure that the employees are carrying out their duties in an effective and satisfactory manner. The performance of the employees can be improved by inspiring employee empowerment, incentive and operation of an effective reward mechanism. In addition, identifying the obstacles towards effective performance and resolving those obstacles through continuous monitoring, training and development involvements will create a basis for several administrative decisions, strategic planning, business plans, succession and competence plans, academic development plans, etc. Also, encouraging personal growth and advancement in the career of the employees by helping them in acquiring the desired knowledge and skills may increase the staff performance and hence competitiveness of the FSL [44].

These factors identified and shown in Figure 8 and Table 3 and Table 4 demand a lot from the human resource team, all of which are based on performance management issues. Thus, performance management is much of a comprehensive and a complex function, as it incorporates activities such as mutual goal setting, continuous progress assessment and regular communication, response and training for improved performance and implementation of employee development plans. In addition, FSL employees should continually be seeking ways to improve their own performance, to take ownership for their work, and reinforce team working, thereby improving worker motivation.

\subsubsection{Improving Competitiveness via Management of Laboratory Processes}

Another aspect of CIF portrayed in Figure 9 is process management, a concept that integrates quality, performance and excellence during accomplishing the tasks in the laboratory that connects the organization with clients (processes). The process parameters identified in this study include $T A T, B_{g}$ and $T_{s c}$ These parameters should be managed while focusing at CIF as they connect with the outside customers or stakeholders.

Process management consist of process design or engineering (which is the development of new processes), process definition (narrative of the current processes), process documentation, analysis and control and process improvement. Process design and definition include describing the essential procedures to accomplish the tasks followed by describing the process using flowcharts, process maps or checklists. This will enable the process pertinent data to be collected, analyzed and improved. There are many process analysis tools, including cause-and-effect diagrams, statistical process control, and trend analyses. In this study, simple statistical analysis using PDFs and CDFs, Pareto charts were able to indicate areas requiring improvements (Tables 1-3). Process improvement may result from improvements based on many, small changes rather than few 


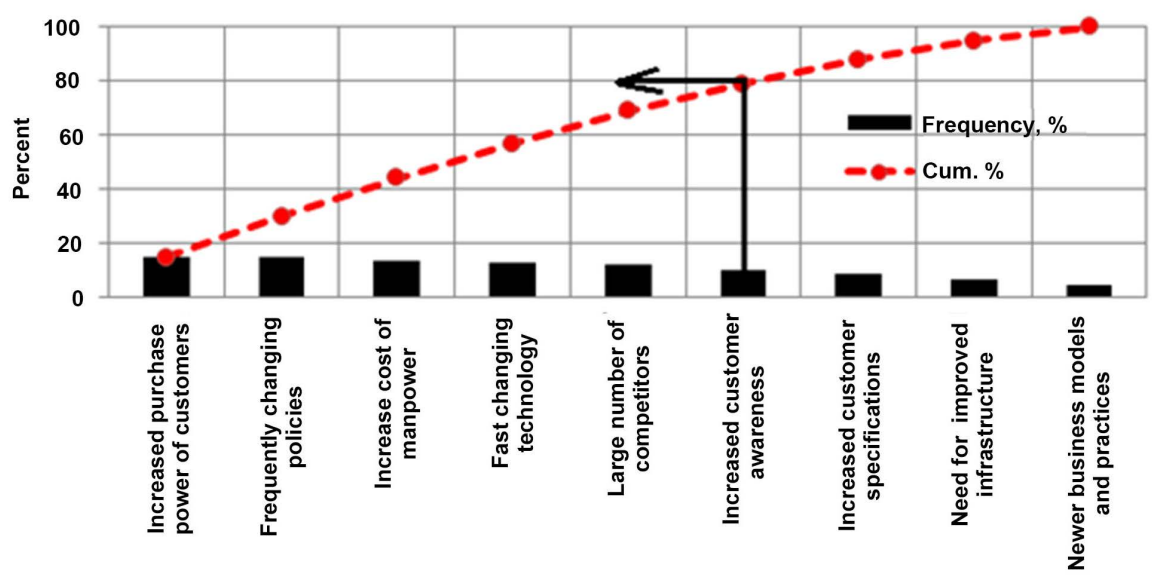

Figure 9. Pareto analysis for ranking the business environment challenges for competitiveness improvement in the FSL.

Table 4. Process management remarks with respect to cause factors.

\begin{tabular}{|c|c|}
\hline Processes & Remarks \\
\hline $\begin{array}{l}\text { Customers of the } \\
\text { process }\end{array}$ & $\begin{array}{l}\text { It is about understanding the customers, their needs and how to provide the services. The customers of a process are the } \\
\text { people who require the products and services. Classified as: external customers (or people who consume the products } \\
\text { and/or services of the FSL) and internal customers (the owners of the next phases in the process within the FSL). }\end{array}$ \\
\hline $\begin{array}{l}\text { Customer/supplier } \\
\text { relationship }\end{array}$ & $\begin{array}{l}\text { Concepts relating to client/supplier relationships and satisfaction are the right to expect quality products and services to } \\
\text { internal or external client. The FSL employees are considered as the next phase in the process employees or the internal } \\
\text { client. Also, each team (individual and team performance) should treat one another as valuable to bring improvement. } \\
\text { In addition, the customer shall determine the product or service satisfaction level and the value expected from the } \\
\text { supplier. }\end{array}$ \\
\hline $\begin{array}{l}\text { Relationship to quality, } \\
\text { schedule and cost }\end{array}$ & $\begin{array}{l}\text { Evaluating and improve processes by establishing process baselines for quality, schedule, and cost. It is about highest } \\
\text { quality products and services on or ahead of schedule and at the lowest possible price which are interdependent. } \\
\text { In order to satisfy and retain its external customers, FSL should be competitive based on analysis and supply chain } \\
\text { turnaround time by providing real-time information to internal and external customers. Design and simplify with } \\
\text { minimal non-value activities for the customers such as defects or constraints. Modify the models based on progressive } \\
\text { decision making, with coexisting engineering management. In addition, empower workers to undo time-wasting } \\
\text { bureaucracy. }\end{array}$ \\
\hline The process owners & $\begin{array}{l}\text { The process owners are the analysts (chemists and technologist) who understand about the processes which accomplish } \\
\text { all activities in action point and accept accountability. Thus, process assessment and development should be done per } \\
\text { day so as TAT reduction to become a reality. }\end{array}$ \\
\hline How to improve & $\begin{array}{l}\text { Knowledgeable and accountable employees of the process are process owners. However, criticism from customers and } \\
\text { suppliers contributes an unlimited need for improvement. }\end{array}$ \\
\hline $\begin{array}{l}\text { Responsible for } \\
\text { improvement process }\end{array}$ & $\begin{array}{l}\text { Improvement is gradual and continuous, intense process redesign or re-engineering, and should be the basic part of } \\
\text { process management and improvements. }\end{array}$ \\
\hline
\end{tabular}

radical changes. Ideas for such changes come from the workers themselves based on the talents of the existing workforce and therefore easier to implement. Also, such changes involved in process management should not require major capital investment, consultants or expensive equipment.

For the purpose of CIF development, detailed review and conceptualization of laboratory processes were done using conceptual frameworks [5] [14] [25]. Given that a process is a series of connected steps or actions with a beginning and an 
end that can be replicated, conceptual models for $T A T, T_{s c}$ and $B_{g}$, were established [5] [14]. The FSL was viewed as a set or hierarchy of laboratory processes that yield analytical reports and services of value to the criminal justice system and investigative science, as well as a set of functions such as chemical or genetic profiling, expert witnessing, accounting, procuring of supplies or services, training and capacity building. Table 4 summarizes the process remarks with respect to the cause factors in relation to arrangement of processes.

For the laboratory to experience the highest levels of success and hence competitiveness, external and internal customers must be satisfied. Each laboratory staff (chemists, accountants and technologists) have the duty to understand their roles as suppliers to internal and external customers. Principally, customers want to be their suppliers' first priority. They deserve perfect analytical reports, which delivered on or ahead of schedule (client's charter). They expect suppliers to be in the improvement mode of operation so that the criminal justice system and the investigative science field are assured of a competitive third opinion expert advice to bring justice.

Process management has potential for improvement. The FSL management should focus on current issues to avoid performing analysis using old methods which are of no use to the criminal justice system. Furthermore, focus may be on quality, whereas reduced turnaround time is crucial. In addition, determining the supplier performance using rating system based on quality, capabilities, conformance to requirements is an important role in process performance measuring.

\subsection{The Role of Policies, Procedures and Plans on Competitiveness Improvement}

The third component of CIF presented in Figure 3 is the role of policies, procedures, programs and plans (strategic plans, staff training program, improvement programs, expenditure framework, etc.). The competitiveness and service viability of forensic science services (FSS) industry as well as its disciplines can potentially be enhanced by planning strategically for future. Laboratory strategic planning, especially in the selected priority disciplines can help set the stage for appropriate responses to the many dynamic changes and driving forces that impact the FSS industry. The FSS strategic planning must take into consideration the laboratory complexities, necessitating comprehensive perception.

FSS faces continuous challenges. It is therefore required to have a constant and enduring strategic planning in a dynamic manner so as to encounter challenges in rapidly changing technologies within the FSS industry and dynamic personnel skills requirement. Planning strategically requires to be focused over the future for a period of years. The planning process must be effective in a continuous manner capturing FSL conditions, external environment, challenges and changing priorities. Regular updates are essential. Areas of emphasis for the FSS strategic planning will change over a period of time as the laboratory service industry priorities undergo transformation. 


\subsection{Identification and Elimination of Wastes in the FSL Processes}

Anything that doesn't increase value in the laboratory processes and in the perception of the customers must be considered as waste and every effort should be made by the management to eliminate that waste. By understanding the different types of waste within the laboratory it is possible to eliminate or reduce impact of such steps to the performance and competitiveness. In this study, such wastes were reached at after detailed analysis of the cause factors, as summarized in $\mathrm{Ta}$ ble 5 .

\subsection{Effect of Laboratory Business Environment on Measured Cause Factors}

Services offered that differentiate FSL from other organizations are those that are associated with criminal justice. While the rest of laboratory services are subjected to competition. Commercial or private laboratories, research cum training laboratories, other government laboratories, are likely to give stiff competition to the FSL. Any laboratory is regarded as competitive if its services consider priority to regular customers, priority services with additional charges for faster services, discount on the cost, and continuous improved/innovative quality services. Also, quick and short delivery of services at reduced waiting time through a provision of mistake-proof or error-free services is a key to competitiveness. The CIF parameters shown in Table 6 were identified through data collection and application of the AHP methodology in ranking the factors. Table 6 shows the importance of the cause factors towards competitiveness and category of indicators to be utilized. The categories denoted as A, B and C have the following extended description: A-Outcome indicators that capture the final objectives of policy; B-Fundamental factor of competitiveness that structurally drives outcomes and which are core levels for policy intervention that can have sustainable impact; and, C-Control indicators that capture potential imbalance that have the potential to create high short term costs even if they don't drive outcomes in the long run.

During development of the CIF, it was important to characterize the cause factors in relation to whether improvements can lead to increased customer awareness and satisfaction, increased number and strength of customer specifications or increased purchase power of customers. Moreover, the cause factors were assessed and rated in relation to coping with fast changing technology, large number of competitors, newer business models and practices, and also on the need for improved business infrastructure. Newer business models in the public laboratory like FSL are difficult to implement, giving chance to competitors in implementing such models like private sector and research institutions, laboratories. The last rating was focused on whether the cause factors are affected by frequently changing government policies or increased cost of manpower in order to improve, as shown in Table 7.

Using the total score determined from summation of the rating values for each challenge found in the business environment, as presented in Table 7, it 
Table 5. Wastes identified in FSL processes and possible means of elimination.

\begin{tabular}{|c|c|c|}
\hline The waste & Definition & Possible means of elimination \\
\hline Waiting & $\begin{array}{l}\text { Analysis work in the process has stopped due to bottlenecked } \\
\text { operations, equipment changeover and services } \\
\text { Also, system response time, approvals from the laboratory } \\
\text { manager may take long depending on the type of case and samples } \\
\text { involved (such as challenging samples) } \\
\text { Administrative duties for Director may delay approval of reports } \\
\text { Lack of supplies-reagents and other consumables may cause delay } \\
\text { in laboratory processes }\end{array}$ & $\begin{array}{l}\text { - Equipment reliability such as Genetic analyzer, } \\
\text { LCMS/MS through Total Productive Maintenance (TPM) } \\
\text { with service contract as part of SCM } \\
\text { - Adequate staffing at the bottlenecked operations such as } \\
\text { Backlog Reduction } \\
\text { - Improve system reliability-scientific report capacity } \\
\text { building } \\
\text { - Push decision-making down to lower levels, that includes } \\
\text { the users, technologists } \\
\text { - Cross-train employees so that work can continue in } \\
\text { - } \text { absence (e.g. top managers) } \\
\text { - ultimately shooting for a batch size of one } \\
\text { - Increase number of identification equipment }\end{array}$ \\
\hline
\end{tabular}

- Printing analytical report before completing analyzing all the data

- Purchasing items such as reagents and other perishables that are consumed seasonally or before they are needed

Overproduction

- Producing reports that are not needed

- Purchasing equipment that are rarely used

- Over staffing in some areas

- High sample influx and too many case-files arriving in short period of time

- Cross contamination, wrong labeling or overheating in re-amplification due to power interruption.

Defects

- Multiple profile, contaminated STR profile

- Mischaracterization of drugs of abuse

- Defective or degraded biological samples

- Inoperative machines lying without service or maintenance
- Establish a flow sequence to satisfy the downstream customer or supervisor (manager)

- Create workplace SOPs, guidelines and regulations for each process

- Create signal devices to prevent over processing, e.g. FIFO lanes
- People's creativity, ideas, and abilities are not fully tapped

Under-utilized - Limited employee authority and responsibility for basic tasks, human resources processing management command and control

- Losing ideas, skills, and improvements by not listening to employees
- Error-proof steps-working in set of two individuals

- Decontamination of working bench and the FS laboratory processes

- Good laboratory practices especially Checklists

- Stocktaking of functioning instruments and equipment

- Establishing and maintaining the service contract

- Preventive maintenance schedule adhered according to manufacturer and installation engineer
- Processing of more samples or duplicate samples of the same case-file

- Taking unneeded steps to process the samples that have shown to have no trace of searched chemical or low DNA

- Inefficient processing due to poor tool and product design

- Also, re-entering data, extra copies, unnecessary or excessive reports

- Lack of statistical or arbitrary resampling techniques for similar items such as pellets or sachets of drugs of abuse
- Institute the academic development program and consider tapping the employees with high complex longevity

- Initiate employee suggestion systems

- Form teams to solve process problems

- Perform preliminary/presumptive tests before undergoing into the major processes

- Remove unnecessary steps

- Use design for as manufactured for the specific instrument with the specified ratios

- Stop unnecessary signoffs and reviews 
- Movement of work or paperwork, sample, from one step to the next step in the analytical process or from one place to the other

Transportation - Long distance movement between buildings or time consumed to reach the next location for processing

- Sample management-proper packaging and storage for sample transportation
- Make the distance over which something is moved as short as possible

Consider work cells and co-located teams

- Establish chain of possession forms and adhere chain of custody and sample integrity
- Any supply that is in excess or less, hence performing stocktaking to avoid pending cases, creating backlogging. Any form of batch processing

Inventory

- Producing more profiles, analytical or computing statistical data, than customer demand or submission

- Movement of people, staff reallocation and placement

- Movement of analysts during processing Use of network for data transfer

Motion

- Limitation of staff from different work areas into other restricted or private
- Purchase only enough to satisfy your downstream sample process and what is submitted to the laboratory

- Ensure that work arrives at the downstream process when it is required and does not stay pending or put away for storage

- Reducing batch sizes eventually to a batch size of one where necessary, thus reducing the amount of reagent usage

- Create print on demand processes for reports and documents for the specific sample/exhibit of the case-file reducing stationary usage

- Arrange work areas to reduce movement

- Consider cell type processing (each process to have its own cubicle)

- Part trays located close to the worker

- Provide extra fax, copy machines and computers and locate files at work stations

- Use color codes as much as possible to differentiate processing areas or laboratory coats

Table 6. Measured cause factors identified to affect FSL competitiveness.

Parameter

Importance towards competiveness improvement

Category of indicators

Backlog, $B_{g} \quad$ Customer focus. Employee fatigue, frustration and complaints from the public.

A, C

Turnaround time, TAT Quality, capacity, customer focus.

Important influence on competitiveness.

A, C

Individual component, culture and trust for analysts; individual behavior and interactions between

Absenteeism, $A_{b}$

Academic development Adequately trained human capital is required to support business activities as well as to develop index, $A_{d} \quad$ innovative capacity and entrepreneurship.

Complex longevity, Knowledgeable and experienced employees over FSL processes are required to carry out and supervise Supply chain time, $T_{s c}$ individuals are the core aspects of productivity. Denotes also interactions between individuals and organization. others completely, without the negative aspects of longevity.

Tracking of procured supplies such as reagents, and instruments to obtain proper resources and provide quality and timely forensic services. Starting from the time the order request is placed by the user department within FSL to the time the order is supplied and payment is made and acknowledged by

$\mathrm{A}, \mathrm{B}, \mathrm{C}$ the supplier. It is the overall efficiency of the supply chain. 
Table 7. Rating of the cause factors based on applicability of competitiveness challenges in the FSL business environment $(\sqrt{ } \sqrt{ }=$ high, $\sqrt{ } \sqrt{ }=$ medium, $\sqrt{ }=$ low).

\begin{tabular}{|c|c|c|c|c|c|c|c|c|c|}
\hline Cause factor & $\begin{array}{c}\text { Increased } \\
\text { customer } \\
\text { awareness }\end{array}$ & $\begin{array}{c}\text { Increased } \\
\text { customer } \\
\text { specifications }\end{array}$ & $\begin{array}{c}\text { Increased } \\
\text { purchase power } \\
\text { of customers }\end{array}$ & $\begin{array}{c}\text { Fast changing } \\
\text { technology }\end{array}$ & $\begin{array}{c}\text { Large } \\
\text { number of } \\
\text { competitors }\end{array}$ & $\begin{array}{c}\text { Newer } \\
\text { business } \\
\text { models and } \\
\text { practices }\end{array}$ & $\begin{array}{c}\text { Need for } \\
\text { improved } \\
\text { infrastructure }\end{array}$ & $\begin{array}{l}\text { Frequently } \\
\text { changing } \\
\text { policies }\end{array}$ & $\begin{array}{l}\text { Increase cost } \\
\text { of manpower }\end{array}$ \\
\hline Backlog, $B_{g}$ & $\sqrt{ } \sqrt{ }$ & $\sqrt{ } \sqrt{ }$ & $\sqrt{ } \sqrt{ }$ & $\sqrt{ } \sqrt{ }$ & $\sqrt{ } \sqrt{ }$ & $\sqrt{ }$ & $\sqrt{ }$ & $\sqrt{ }$ & $\sqrt{ } \sqrt{ } \sqrt{ }$ \\
\hline $\begin{array}{c}\text { Turnaround } \\
\text { time, } T A T\end{array}$ & $\sqrt{ }$ & $\sqrt{ } \sqrt{ }$ & $\sqrt{ } \sqrt{ }$ & $\sqrt{ } \sqrt{ } \sqrt{ }$ & $\sqrt{ } \sqrt{ }$ & $\sqrt{ }$ & $\sqrt{ } \sqrt{ }$ & $\sqrt{ } \sqrt{ }$ & $\sqrt{ } \sqrt{ }$ \\
\hline Absenteeism, $A_{b}$ & $\sqrt{ }$ & $\sqrt{ }$ & $\sqrt{ } \sqrt{ }$ & $\sqrt{ }$ & $\sqrt{ } \sqrt{ }$ & $\sqrt{ }$ & $\sqrt{ }$ & $\sqrt{ } \sqrt{ } \sqrt{ }$ & $\sqrt{ } \sqrt{ }$ \\
\hline $\begin{array}{l}\text { Academic } \\
\text { development } \\
\text { index, } A_{d}\end{array}$ & $\sqrt{ } \sqrt{ }$ & $\sqrt{ }$ & $\sqrt{ } \sqrt{ }$ & $\sqrt{ } \sqrt{ } \sqrt{ }$ & $\sqrt{ } \sqrt{ } \sqrt{ }$ & $\sqrt{ }$ & $\sqrt{ }$ & $\sqrt{ } \sqrt{ } \sqrt{ }$ & $\sqrt{ } \sqrt{ } \sqrt{ }$ \\
\hline $\begin{array}{c}\text { Complex } \\
\text { longevity, } L_{c}\end{array}$ & $\sqrt{ } \sqrt{ }$ & $\sqrt{ } \sqrt{ }$ & $\sqrt{ } \sqrt{ }$ & $\sqrt{ } \sqrt{ }$ & $\sqrt{ }$ & $\sqrt{ }$ & $\sqrt{ }$ & $\sqrt{ } \sqrt{ }$ & $\sqrt{ } \sqrt{ }$ \\
\hline $\begin{array}{l}\text { Supply chain } \\
\text { time, } T_{s c}\end{array}$ & $\sqrt{ }$ & $\sqrt{ }$ & $\sqrt{ } \sqrt{ }$ & $\sqrt{ } \sqrt{ }$ & $\sqrt{ } \sqrt{ }$ & $\sqrt{ }$ & $\sqrt{ }$ & $\sqrt{ } \sqrt{ } \sqrt{ }$ & $\sqrt{ }$ \\
\hline Total score & 10 & 9 & 15 & 13 & 12 & 5 & 7 & 15 & 14 \\
\hline
\end{tabular}

was possible to arrange the challenges in descending order, and apply Pareto analysis, as summarized in Figure 9. Based in Figure 9, there are five challenges in the business environment that the laboratory needs to address first in order to improve its competitiveness by $80 \%$ while utilizing $20 \%$ of the rather limited resources. These challenges are: increased purchase power of customers; frequently changing government policies; increased cost of manpower; fast changing technology; large number of competitors; and, increased customer awareness, in that order of importance. The last three challenges, contribute only $20 \%$ of the problems facing the competitiveness of the laboratory.

Furthermore, Table 8 shows the means of which the above nine challenges in the business environment affect FSL via the six cause factors identified and measured in this study. The business environment challenges are also arranged in the same order as presented in the Pareto chart (Figure 9).

\subsection{Application of D-MAIC Methodology in Competitiveness Improvement}

In this study, D-MAIC methodology was selected as a tool to provide a roadmap that can be followed for competitiveness improvement for the laboratory. The term D-MAIC comes from the five principle steps in this process which include Define, Measure, Analyze, Improve, and Control as shown in Figure 10. Based in Figure 10, the effects and impacts of the cause factors on FSL competitiveness were established in specific details, to increase the probability of designing or remodeling for a better improvement. After identifying the cause factors, measurements and quantification of the variations were made to determine the current status of the cause factors as a study parameter in the specific discipline of the laboratory. Analyze implies quantification of the current status, followed by analysis and presentation of the data collected. In this study, data collected on $T A T, A_{b}, B_{g}, A_{d} L_{\mathcal{c}}$ and $T_{s c}$ were analyzed and presented in understandable 
Table 8. Summary of recommendations for the business environment challenges for competitiveness improvement in the FSL based on cause factors.

\begin{tabular}{|c|c|c|c|c|c|c|c|c|}
\hline Cause factor & $\begin{array}{l}\text { Increased } \\
\text { customer } \\
\text { awareness }\end{array}$ & $\begin{array}{c}\text { Increased } \\
\text { customer } \\
\text { specifications }\end{array}$ & $\begin{array}{l}\text { Fast changing } \\
\text { technology }\end{array}$ & $\begin{array}{c}\text { Large } \\
\text { number of } \\
\text { competitors }\end{array}$ & $\begin{array}{c}\text { Newer business } \\
\text { models and } \\
\text { practices }\end{array}$ & $\begin{array}{c}\text { Need for } \\
\text { improved } \\
\text { infrastructure }\end{array}$ & $\begin{array}{c}\text { Frequently } \\
\text { changing policies }\end{array}$ & $\begin{array}{l}\text { Increase cost of } \\
\text { manpower }\end{array}$ \\
\hline Backlog, $B_{g}$ & $\begin{array}{l}\text { - Customers aware } \\
\text { of } B_{g} \text { on FSL will } \\
\text { non away to } \\
\text { competitors }\end{array}$ & $\begin{array}{l}\text { When } \\
\text { customer } \\
\text { specify their } \\
\text { requirements } \\
\text { and FSL falls } \\
\text { into } B_{g} \text { and } A_{b} \\
\text { high customer } \\
\text { will run away }\end{array}$ & $\begin{array}{l}\text { - } B_{g} \text { can be eliminated by } \\
\text { enquiring new equip } \\
\text { new methods } \\
\text { - Extended Bg will have } \\
\text { no excuse before } \\
\text { customers } \\
\text { - Extended } T A T \text { will have } \\
\text { no excuse } \\
\text { - FSL will need to procure } \\
\text { new equip that are faster }\end{array}$ & $\begin{array}{l}\text { High } B_{g} \text { will } \\
\text { turn customers } \\
\text { to other service } \\
\text { to other service } \\
\text { providers } \\
\text { (competitors) }\end{array}$ & $\begin{array}{l}B_{g} \text { will show } \\
\text { down FSL to } \\
\text { enter new } \\
\text { business } \\
\text { practices }\end{array}$ & $\begin{array}{l}\text { This factor has } \\
\text { to be eliminated } \\
\text { or reduced to } \\
\text { minimal to } \\
\text { improve } \\
\text { business }\end{array}$ & $\begin{array}{l}\text { - Government may } \\
\text { reactively to } B_{g} \\
\text { packing FSL to } \\
\text { accountability } \\
\text { - Government } \\
\text { policies may put } B_{g} \\
\text { on spotlight } \\
\text { - Need for Expert } \\
\text { witness (EW) to } \\
\text { appear in courts at } \\
\text { increased number } \\
\text { of criminal case } \\
\text { forces FSL to have } \\
\text { high } B_{g}\end{array}$ & $\begin{array}{l}\text { FSL and Government } \\
\text { unable to provide } \\
\text { more staff to lower } A_{b} \\
\text { due to high cost of } \\
\text { salaries for such } \\
\text { specific experts }\end{array}$ \\
\hline $\begin{array}{c}\text { Turnaround } \\
\text { time, TAT }\end{array}$ & $\begin{array}{l}\text { - Slight extended } \\
T A T \text { leads to } \\
\text { complaints } \\
\text { - Poor FSL image } \\
\text { on average } \\
\text { customers }\end{array}$ & $\begin{array}{l}\text { Customer } \\
\text { specifies } T A T \\
\text { and fast tests if } \\
T A T \text { is still too } \\
\text { long, they run } \\
\text { away }\end{array}$ & $\begin{array}{l}\text { - Extended TAThave no } \\
\text { excuse } \\
\text { - FSL will need to procure } \\
\text { new equipment that are } \\
\text { faster }\end{array}$ & $\begin{array}{l}\text { With available } \\
\text { service providers } \\
\text { at disposal } \\
\text { customers will } \\
\text { opt for shorter } \\
\text { TAT services }\end{array}$ & $\begin{array}{l}\text { - The customers } \\
\text { will run away } \\
\text { where service } \\
\text { providers offer } \\
\text { new business } \\
\text { models/ } \\
\text { practices } \\
\text { - FSL will be } \\
\text { forced to } \\
\text { abandon its old } \\
\text { model for } \\
\text { business or } \\
\text { perish }\end{array}$ & $\begin{array}{l}\text { - To improve its } \\
\text { business FSL } \\
\text { must tower } \\
T A T ; \\
\text { • Expenses may } \\
\text { fall on new } \\
\text { equipment and } \\
\text { increased } \\
\text { number of staff }\end{array}$ & $\begin{array}{l}\text { - Transfer of staff } \\
\text { with high } L_{c} A_{d} \text { will } \\
\text { affect FSL } \\
\text { - FSL be coming on } \\
\text { government } \\
\text { spotlight will be } \\
\text { forced to reduce } \\
T A T \text { at any expense } \\
\text { - This puts FSL at } \\
\text { pressure which may } \\
\text { lead to errors }\end{array}$ & $\begin{array}{l}\text { Longer } T A T \text { caused } \\
\text { by lack of manpower } \\
\text { may lead to expenses } \\
\text { on increased labor } \\
\text { force } \\
\text { Increasing staff } \\
\text { without increasing } \\
\text { supervisors may not } \\
\text { help } \\
\text { Always time is re for } \\
\text { new workforce }\end{array}$ \\
\hline $\begin{array}{c}\text { Absenteeism, } \\
A_{b}\end{array}$ & $\begin{array}{l}\text { Leads untimeliness } \\
\text { of services will lead } \\
\text { complaints and } \\
\text { tarnished image of } \\
\text { FSL and poor } \\
\text { competitiveness }\end{array}$ & $\begin{array}{l}\text { High } A_{b} \text { leads } \\
\text { to unmet } \\
\text { customer } \\
\text { specification } \\
\text { and demands }\end{array}$ & $\begin{array}{l}\text { - Available technologies } \\
\text { for tacking } A_{b} \\
\text { - New equip can be used } \\
\text { to produce fast results } \\
\text { and counteract } \\
A_{b} \text { effects } \\
\text { - New service providers } \\
\text { with high-tech } \\
\text { equipment } \\
\text { - With high } A_{b} \\
\text { customers will opt for } \\
\text { new service providers }\end{array}$ & $\begin{array}{l}\text { Increased } A_{b} \text { will } \\
\text { allow customers } \\
\text { to opt for } \\
\text { competitors to } \\
\text { get services }\end{array}$ & $\begin{array}{l}\cdot \text { High } A_{b} \\
\text { hinders changes } \\
\text { in business } \\
\text { model and new } \\
\text { practice } \\
\text { - Competitors } \\
\text { with new } \\
\text { business models } \\
\text { and practices } \\
\text { may arise and } \\
\text { gain customer } \\
\text { support due to } \\
\text { high } A_{b} \text { in FSL }\end{array}$ & $\begin{array}{l}\text { - Business can } \\
\text { be improved if } \\
A_{b} \text { is reduced } \\
\text { to minimal } \\
\text { - Policy changes } \\
\text { are needed by } \\
\text { FSL to curb } A_{b} \\
\text { and improve } \\
\text { FSL business }\end{array}$ & $\begin{array}{l}\text { - Policy to curb } A_{b} \text { in } \\
\text { government } \\
\text { institutions } \\
\text { has helped FSL to } \\
\text { curb } A_{b} \\
\text { - This will improve } \\
\text { FSL's } \\
\text { competitiveness }\end{array}$ & $\begin{array}{l}\text { - High } A_{b} \text { implies } \\
\text { receiving payments } \\
\text { without working } \\
\text { - Cost of empower } \\
\text { escalates due to high } \\
A_{b} \text { as output is } \\
\text { lowered for the same } \\
\text { pay }\end{array}$ \\
\hline $\begin{array}{c}\text { Academic } \\
\text { development } \\
\text { index, } A_{d} \text { and } \\
\text { Complex } \\
\text { longevity, } L_{c}\end{array}$ & $\begin{array}{l}\text { - High Ad will help } \\
\text { to wider customer' } \\
\text { needs } \\
\text { - Advanced } \\
\text { technical reports }\end{array}$ & $\begin{array}{l}\text { High } A_{d} \text { with } \\
\text { staff advanced } \\
\text { in academic } \\
\text { development, } \\
\text { they will be } \\
\text { able to address } \\
\text { customer } \\
\text { specification } \\
\text { received, and } \\
\text { provide advice } \\
\text { consultancy }\end{array}$ & $\begin{array}{l}\text { - Able to cope with fast } \\
\text { changing technical when } \\
A_{d} \text { is high } \\
\text { - Able to use new in } \\
\text { struments/equipment } \\
\text { - Able to diagnose errors } \\
\text { and design corrective } \\
\text { action } \\
\text { - Capable of setting up } \\
\text { trouble shooting exercises }\end{array}$ & $\begin{array}{l}\text { Able to maintain } \\
\text { the competitive } \\
\text { edge even in } \\
\text { presence of } \\
\text { competitors }\end{array}$ & $\begin{array}{l}\text { High } A_{d} \text { will } \\
\text { allow design of } \\
\text { resent models } \\
\text { but also to cope } \\
\text { with new } \\
\text { business } \\
\text { practices } \\
\text { Capable of } \\
\text { playing } \\
\text { important role }\end{array}$ & $\begin{array}{l}\text { Business } \\
\text { improvement } \\
\text { possible as high } \\
A_{d} \text { will allow } \\
\text { staff to measure } \\
\text { current status, } \\
\text { analyze fund } \\
\text { bottlenecks and } \\
\text { find root causes }\end{array}$ & $\begin{array}{l}\text { Capability to cope } \\
\text { with changing } \\
\text { polices high when } A_{d} \\
\text { is high among } \\
\text { employees }\end{array}$ & $\begin{array}{l}\text { High } A_{d} \text { calls for } \\
\text { higher salaries and } \\
\text { hence increased } \\
\text { manpower cost } \\
\text { It is a give and take } \\
\text { phenomena } \\
\text { Ensure } A_{d} \\
\text { corresponds with } \\
\text { performance and } \\
\text { increased revenue to } \\
\text { create balance }\end{array}$ \\
\hline $\begin{array}{l}\text { Supply chain } \\
\text { time, } T_{s c}\end{array}$ & $\begin{array}{l}\text { Suppliers are aware } \\
\text { of their rights } T_{c s} \\
\text { for internal process } \\
\text { must improve } \\
\text { State supplier } \\
\text { obligations clearly } \\
\text { in contracts, a } \\
\text { prior, } \\
T_{s c} \text { for external } \\
\text { process must } \\
\text { improve }\end{array}$ & $\begin{array}{l}\text { FSL must state } \\
\text { specification } \\
\text { precisely for } \\
\text { suppliers and } \\
\text { stick to } \\
\text { procedures }\end{array}$ & $\begin{array}{l}\text { Improvise new systems to } \\
\text { take advantage of } \\
\text { technology and shorten } \\
T_{s c} \text { for the Labs to receive } \\
\text { services/goods on time; } \\
\text { this will help FSL at } \\
\text { competitive advantage }\end{array}$ & $\begin{array}{l}\text { Long } T_{s c} \text { will } \\
\text { pare way to } \\
\text { competitors as } \\
\text { FSL services are } \\
\text { not provided on } \\
\text { time }\end{array}$ & $\begin{array}{l}\text { Extended } T_{s c} \text { will } \\
\text { not fit into new } \\
\text { business models } \\
\text { leading to last } \\
\text { competitors }\end{array}$ & $\begin{array}{l}\text { Reduced } T_{s c} \text { will } \\
\text { lead to improve } \\
\text { business }\end{array}$ & $\begin{array}{l}\text { - } T_{\mathrm{sc}} \text { need to change, } \\
\text { and minimize } T_{s c} \text { to } \\
\text { cope with } \\
\text { government } \\
\text { policies } \\
\text { - New regulation } \\
\text { place }\end{array}$ & $\begin{array}{l}\text {-Increase manpower } \\
\text { in PMU unit } \\
\text { - Centralize SCM } \\
\text { - Incur manpower } \\
\text { cost on TSC has }\end{array}$ \\
\hline
\end{tabular}




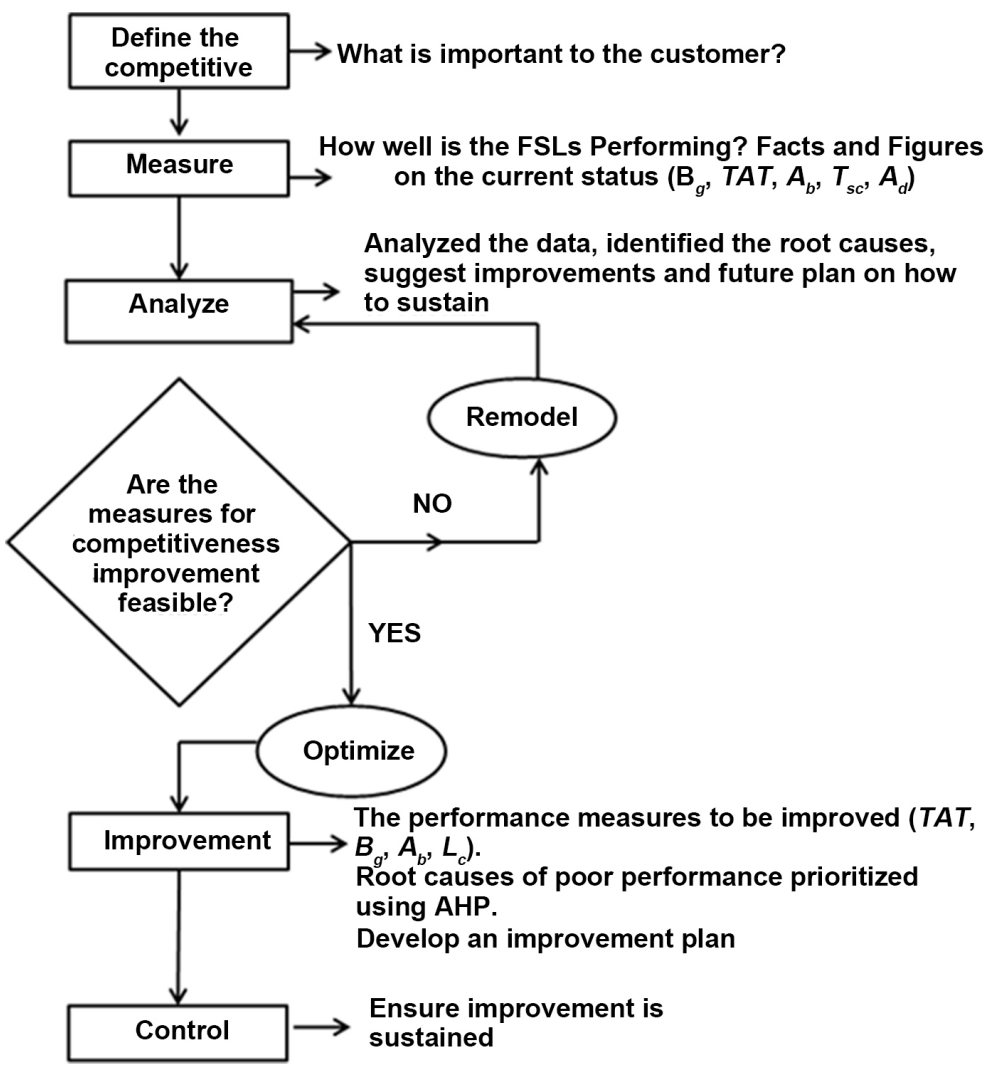

Figure 10. Simple flow chart for competitiveness improvement for FSL based on D-MAIC methodology.

format, [5] [14] [25] [44] showing the criticality of current situation and action required. At this point, it is important to establish a need to redesign or re-model the existing conceptual model of the FSL system or there is a specific cause factor that has to be corrected. Analysis was followed by remodeling or optimization, before improvement and control. In this case control means maintaining the improved system to prevent the system from going back to the initial poor state (sustainability). Table 9 shows the competitiveness improvement framework developed using the detailed D-MAIC methodology for the FSL.

Based in Table 9, the competitiveness improvement framework has been presented in five key steps of D-MAIC but also using 15-step processes with highly detailed process analysis for each step in relation to the cause factors established. The possible measures for improving competitiveness can then be introduced or an optimum can be used for the existing situation suggested as per concepts in Table 9. Also, trial statistics can be designed for the purpose of prioritization as which cause factor gives the highest improvements towards competiveness depending on the client's demands. An example of such analysis is AHP application, used in this study to rank the factors, keeping in mind that the cause factors are interdependent. Subsequently, as stated above implementation of the improvement measures requires controls to be placed so that they can confirm sustainability and prevent recurrence. The control measurements for improvement 
Table 9. FSL Competitiveness improvement framework based on detailed D-MAIC methodology.

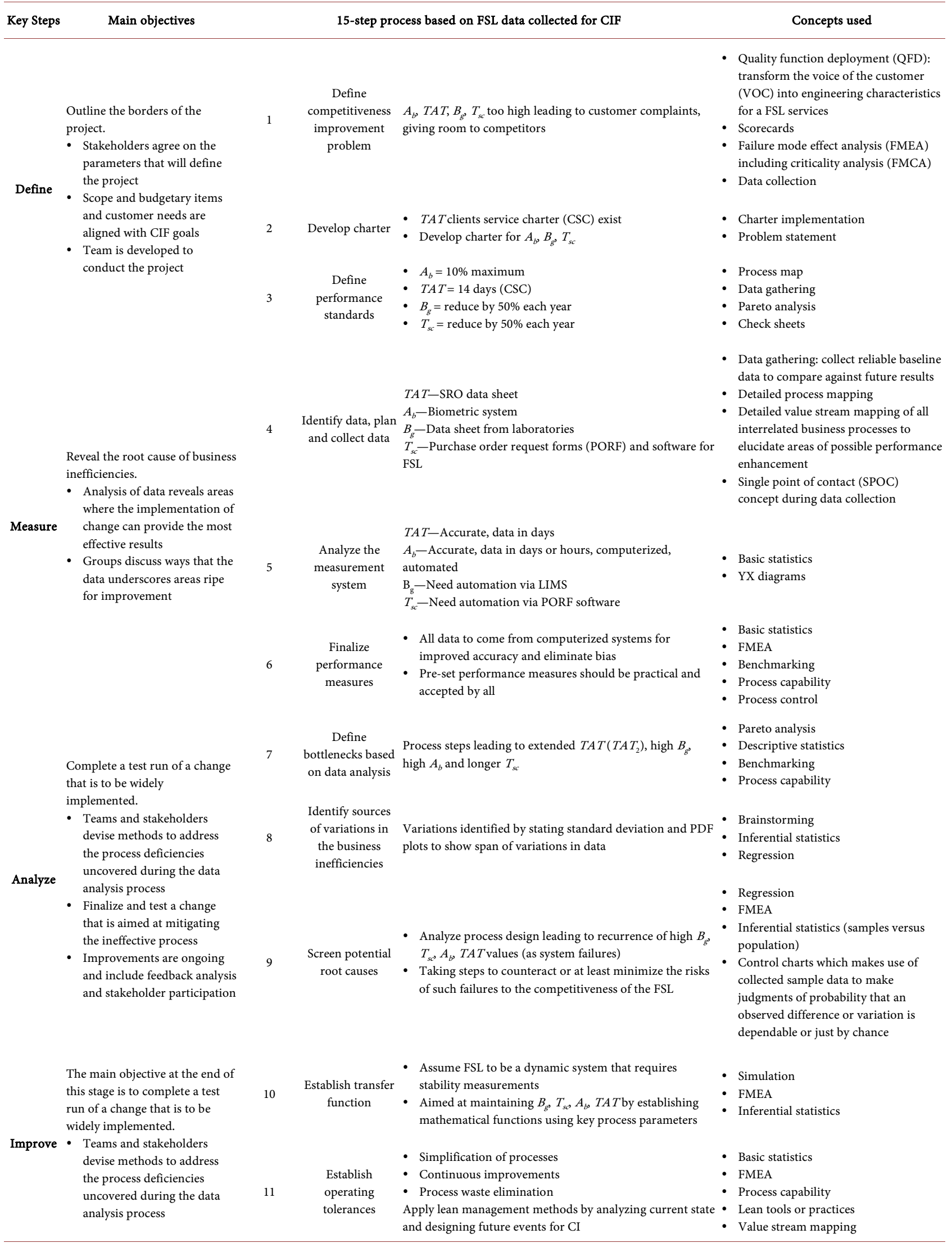




\section{Continued}

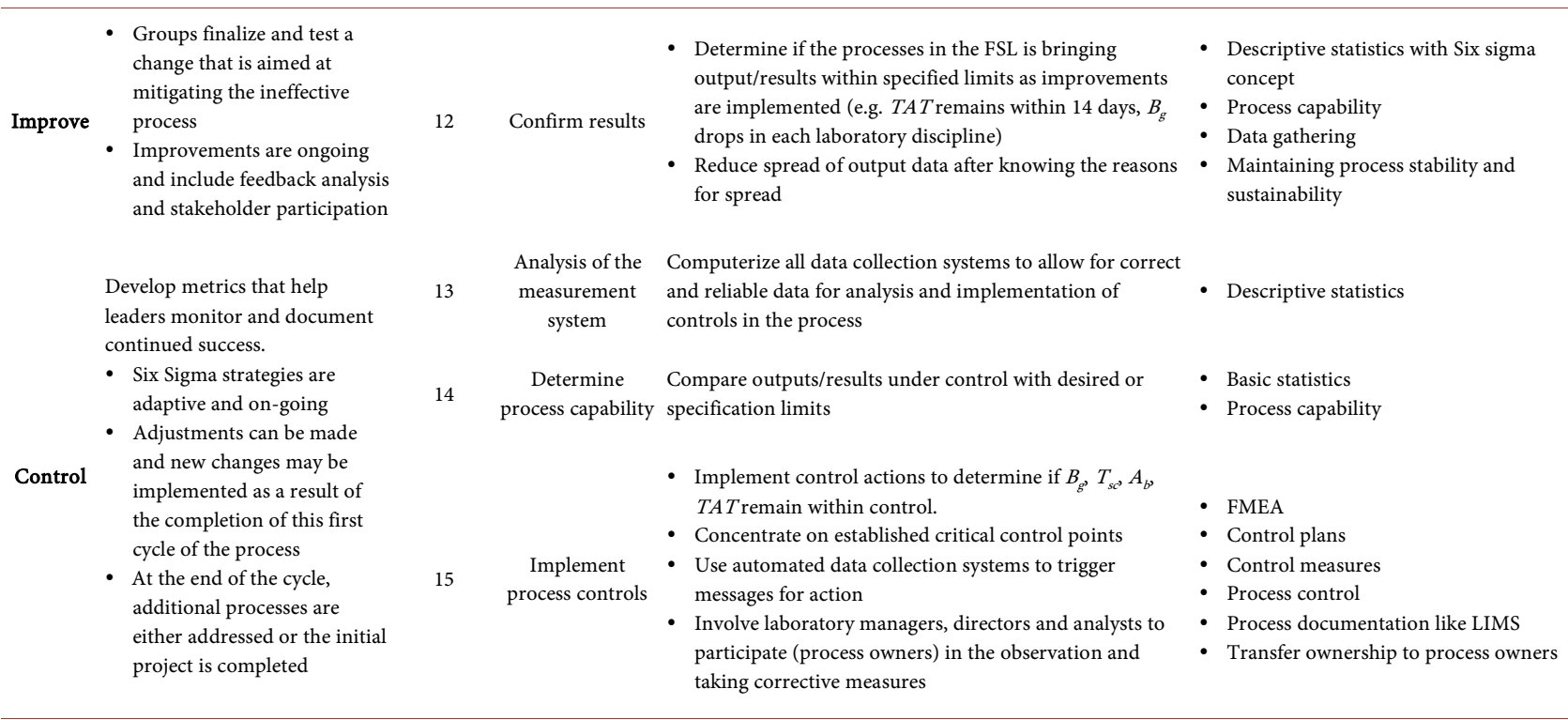

should be scheduled with specific dates, e.g., daily, monthly, yearly, etc. Also, the improvement measures and other related processes have to be documented. Figure 11 presents a flow chart for competitiveness improvement based on a detailed D-MAIC methodology using 15 steps presented in Table 9.

\subsection{Lean Practices for Competitiveness Improvement}

A firm's competitiveness advantage grows fundamentally out of the value it can provide to its clients. For instance, $T A T$, and $T_{s c}$ are the major cause factors that affect strongly or directly the laboratory-client relationship, which can be reduced to improve the competitive edge. The samples and case file processing and management is a unique product which should be managed properly in a way, not offered by any competitor which creates a strong relationship with clients.

Lean process is about FSL being effective and efficient. It begins from the point of understanding the customer requirements, standards and prerequisites and performs the best way to provide the analytical reports and expert opinion. Table 10 is a template for continuously measuring the potential lean practices of FSL, where six lean processes related to the cause factors affecting FSL competitiveness have been analyzed. Where there was no relationship between the cause factors and the lean practices no score was inserted, equivalent to zero score.

The total scores presented in Table 10 were further analyzed using Pareto principle, as shown in Figure 12, based on which, the higher the score the more effective the practice in bringing positive change to the complex and dynamic laboratory business environment. Using Pareto principle, there are three lean practices that can be applied in order to improve competitiveness of the FSL by $80 \%$, while utilizing $20 \%$ of the resources, as shown in Figure 12 . These lean practices are: continuous improvement of services, customer satisfaction and record keeping. Thus, to fasten competitiveness improvement for the laboratory, 
Table 10. Applicability of potential of lean practices for improving competitiveness of the FSLs for the measured factors affecting competitiveness (rating: $\sqrt{ } \sqrt{ } \sqrt{ }=$ high, $\sqrt{ } \sqrt{ }=$ medium, $\sqrt{ }=$ low).

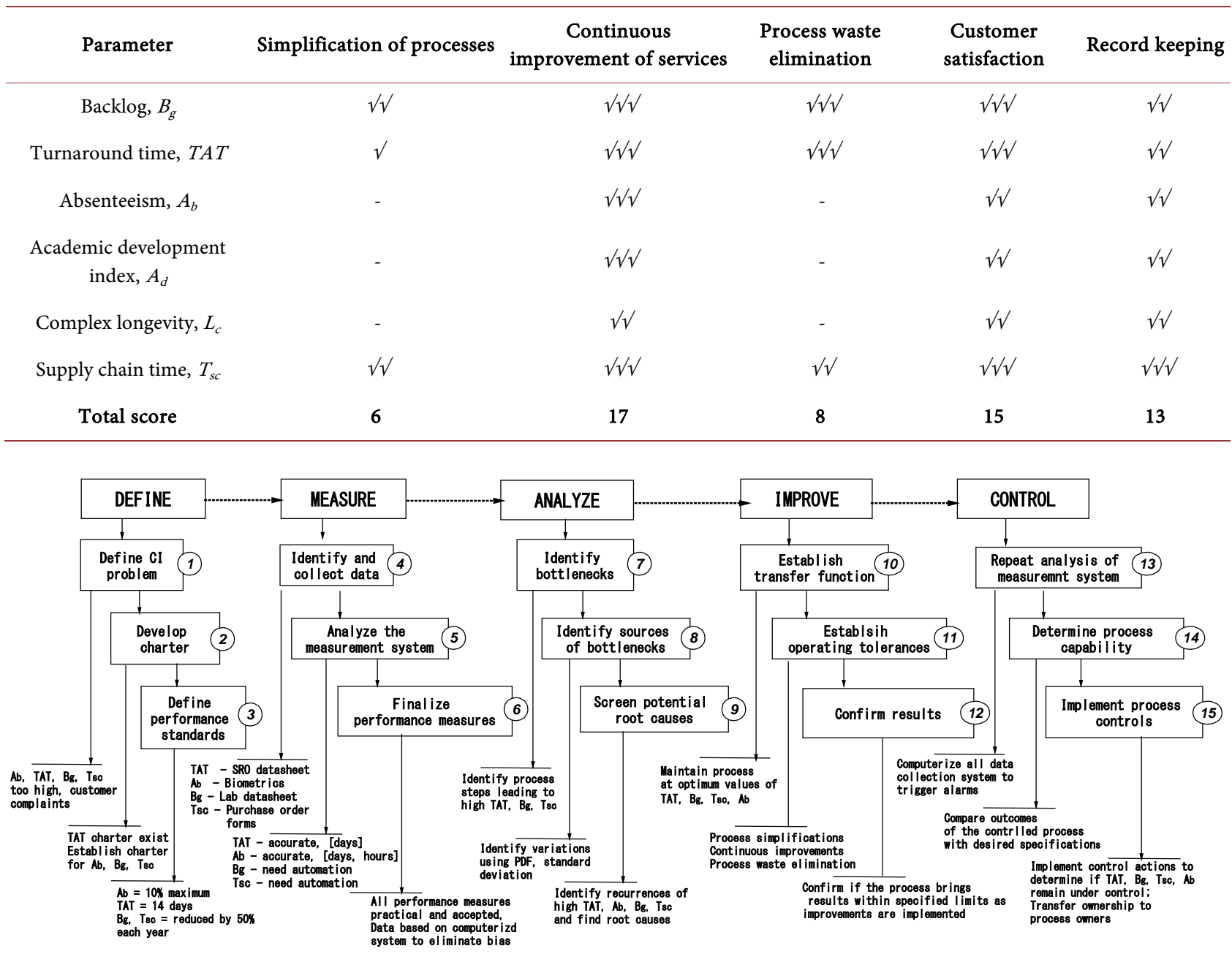

Figure 11. Detailed flow chart for competitiveness improvement in the FSL based on detailed D-MAIC methodology.

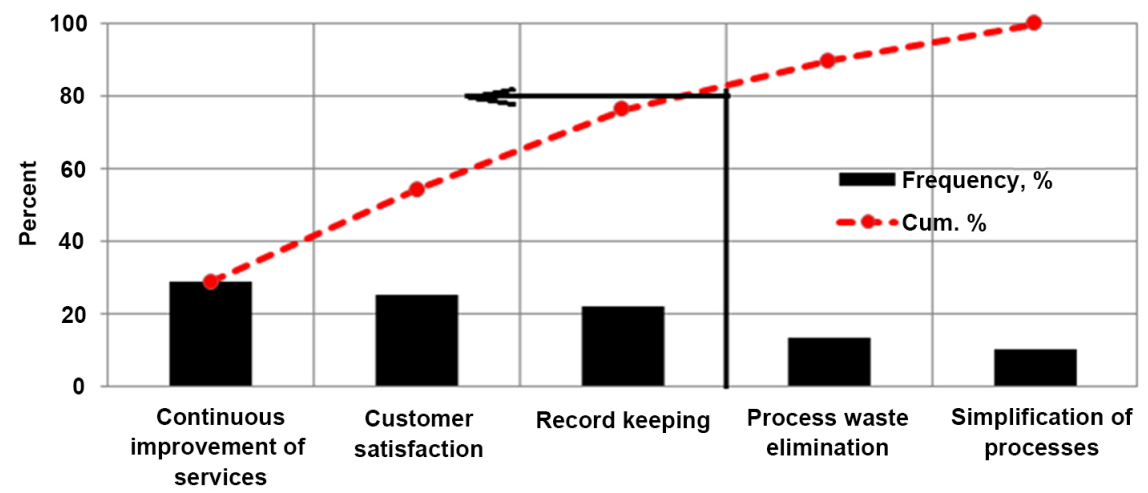

Figure 12. Pareto analysis of the lean practices for improving FSL competitiveness.

it is important to understand how the competitors benefit from the bottlenecks or problems facing the organization and also to find out how the external competitive environment affects the measured factors. 


\subsection{Improving Operational Competitiveness in the Laboratory}

In relation to the CI process and the cause factors studies, it was possible to establish from literature, the methods for improving operational competitiveness in the laboratory, that is economic added value, total shareholder return, value curve, capacity maturity model, and assets processes performance framework. Table 11 defines each method in relation to the cause factors established in this study. Thus, directors and laboratory managers should be aware of the operational competitiveness requirements being placed on them at the conceptual level, whereby, attempts to reorient the way in which they operate shall be observed significantly and that a continuous improvement culture should be slowly accommodated within the FSL such that the gap between Government policy on the one hand and implementation on the other is narrowed.

After observing the cause factors that affect the FSL competitiveness, it is important to effect methods that can assist in improving the competitiveness. Table 12 shows how these methods, forces and strategies to achieve better performance can be integrated to improve competitiveness for each of cause factors in accordance with the four competitiveness paradigms. The features of operational competiveness are action-oriented in design and focus on critical factors that are impacting the FSL competitiveness. There is a need to improve operational competitiveness of the laboratory. The abbreviations used for different methods for improvement of operational competitiveness can be found in Table 11, which fall on financial analysis category.

Based on Table 12, the methods for improving operational competitiveness play an important role in ensuring that the laboratory makes an important progress in changing the way in which it operates and hence become more competitive. It should be noted that operational competitiveness improvement is strongly related to EVA, TSR, VC, CMM and APPF. Additional methods like Balanced Scorecard (BSC) and Integrated Value Management (IVM), respectively, are also suggested for CIF.

\subsection{Presentation of the Complete Competitiveness Improvement Framework for Laboratories}

Finally, methods for improving competitiveness in FSL were outlined by combining the competitiveness paradigms with the methods to improve operational competitiveness. At the end, the complete Competitiveness Improvement Framework in the FSL was presented using a flow chart presented in three sections shown in Figures 13(a)-(c). The CIF for FSL is developed using the cyclic nature of the FSL processes. Furthermore, variations in the backlogs, components of the total turnaround time, SCM performance measures, staff absenteeism and in the staff academic and professional development were utilized from baseline data collected, as summarized in Figure 13(a).

The flow chart for a complete competitiveness improvement framework consists of five layers or phases: first the baseline study, data analysis and presentation. 
Table 11. Methods and financial measures for improving operational competitiveness.

\begin{tabular}{|c|c|c|c|}
\hline \multicolumn{2}{|c|}{ Methods identified } & \multicolumn{2}{|r|}{ Competitiveness improvement measures (CIM) } \\
\hline EVA & $\begin{array}{l}\text { Economic added } \\
\text { value }[65][66]\end{array}$ & $B_{g}, T A T, A_{b}, A_{d}$ and $T_{s c}$ & $\begin{array}{l}\text { - Financial measure to determine the true economic profit of an organization } \\
\text { - Considers firms profit after tax and potential investments [65] }\end{array}$ \\
\hline TSR & $\begin{array}{l}\text { Total shareholder } \\
\text { return [67] [68] }\end{array}$ & $T_{s c} T A T, A_{d}$ and $L_{c}$ & $\begin{array}{l}\text { - A measure to calculate the return to the investor( Government, in this case) } \\
\text { - Includes capital gains and dividends [67] } \\
\text { - An internal return of cash flows during a certain period }\end{array}$ \\
\hline VC & Value curve [69] & $B_{g}, T A T, A_{b}, A_{d}$ and $T_{s c}$ & $\begin{array}{l}\text { - Graphical representation showing firms relative level for elements important to the } \\
\text { FSL (customer perceptions in that industry on strategies factors) [69] } \\
\text { - Used by firms to compare their position in relation to their rivals and competitiveness }\end{array}$ \\
\hline CMM & $\begin{array}{l}\text { Capability maturity } \\
\text { model [70] }\end{array}$ & $B_{g s} T A T, A_{b}, A_{d}$ and $T_{s c}$ & - A method to improve firms processes and ability to meet project objects \\
\hline APPF & $\begin{array}{l}\text { Assets processes } \\
\text { performance } \\
\text { framework [71] [72] }\end{array}$ & $T A T, T_{s c}$ & $\begin{array}{l}\text { - Used mainly by Government and Public sectors to evaluate performance of } \\
\text { departments and service units } \\
\text { - Include all assets, buildings, equipment, processes and performance of departments }\end{array}$ \\
\hline
\end{tabular}

Table 12. Competitiveness paradigm, forces, strategies and methods to improving competitiveness for each cause factors.

\begin{tabular}{|c|c|c|c|c|}
\hline Backlog, $B_{g}$ & $\begin{array}{l}\text { Category of } \\
\text { competitive } \\
\text { paradigm }\end{array}$ & $\begin{array}{c}\text { Forces that } \\
\text { determine } \\
\text { competitiveness }\end{array}$ & $\begin{array}{l}\text { Strategies to achieve } \\
\text { better performance }\end{array}$ & Methods to improve operational competiveness \\
\hline Backlog, $B_{g}$ & $\mathrm{P}, \mathrm{Q}, \mathrm{I}$ & IR, $\mathrm{N}-$ minimize & $\begin{array}{l}\text { LCA-Lower cost } \\
\text { advantages, Focus }\end{array}$ & EVA, VCI, VC, CMM, IVM, BSC \\
\hline Turnaround time, $T A T$ & $\mathrm{P}, \mathrm{Q}, \mathrm{I}$ & $\mathrm{S}_{\mathrm{b}}, \mathrm{IR}, \mathrm{N}-$ minimized & $\begin{array}{l}\text { LCA, Focus } \\
\text { D-differentiation }\end{array}$ & EVA, TSR, VC, BSC, CMM, APPF, IVM \\
\hline Absenteeism, $A_{b}$ & $\mathrm{C}, \mathrm{P}, \mathrm{Q}$ & IR, $\mathrm{N}-$ minimized & $\mathrm{D}$ & EVA, IVM, BSC, CMM \\
\hline $\begin{array}{l}\text { Academic development } \\
\quad \text { index, } A_{d}\end{array}$ & C, Q & $\mathrm{IR}, \mathrm{S}_{\mathrm{b}}$ & D, Focus & EVA, VCI, VC, CMM, IVM, BSC, TSR \\
\hline Complex longevity, $L_{c}$ & $\mathrm{C}$ & - & $\mathrm{D}$ & VCI, CMM, IVM, BSC \\
\hline Supply chain time, $T_{s c}$ & $\mathrm{P}, \mathrm{Q}, \mathrm{I}$ & $\begin{array}{c}\mathrm{S}_{\mathrm{u}}, \mathrm{IR}, \mathrm{B} \\
\mathrm{N}-\text { minimized }\end{array}$ & LCA, Focus-D & EVA, VCI, VC, CMM, APPF, IVM, BSC \\
\hline Legend & \multicolumn{4}{|c|}{$\begin{array}{l}\mathrm{C}-\text { Craftsmanship; } \mathrm{P}-\text { Productivity, Q-Quality, I-Immediacy, } \mathrm{N}-\text { New entrants, IR-Intensity of Rivalry, } \\
S_{u}-\text { Suppliers, } S_{b}-\text { Substitutes, } \mathrm{B}-\text { Buyers }\end{array}$} \\
\hline
\end{tabular}

The second layer involves identification and elimination of wastes, followed by a third layer, that is, use of D-MAIC methodology. Layer four comprises of assessing the applicable challenges in the laboratory business environment in relation to cause factors and ranking by Pareto analysis, also shown in Figure 13(a).

Phase five involves grouping the cause factors according to measures for improving competiveness considering the CI dimensions (process, performance, and planning dimensions) and application of operational improvement methods (economic value, total shareholder, value curve, capability maturity model, and assets processes performance framework) to the cause factors followed by ranking of the methods using Pareto analysis as shown in Figure 13(b) and Figure $13(\mathrm{c})$.

The CIF developed provides a common reference for a diverse set of FSLs, to assist in organizing the competitiveness improvement process, re-framing the 


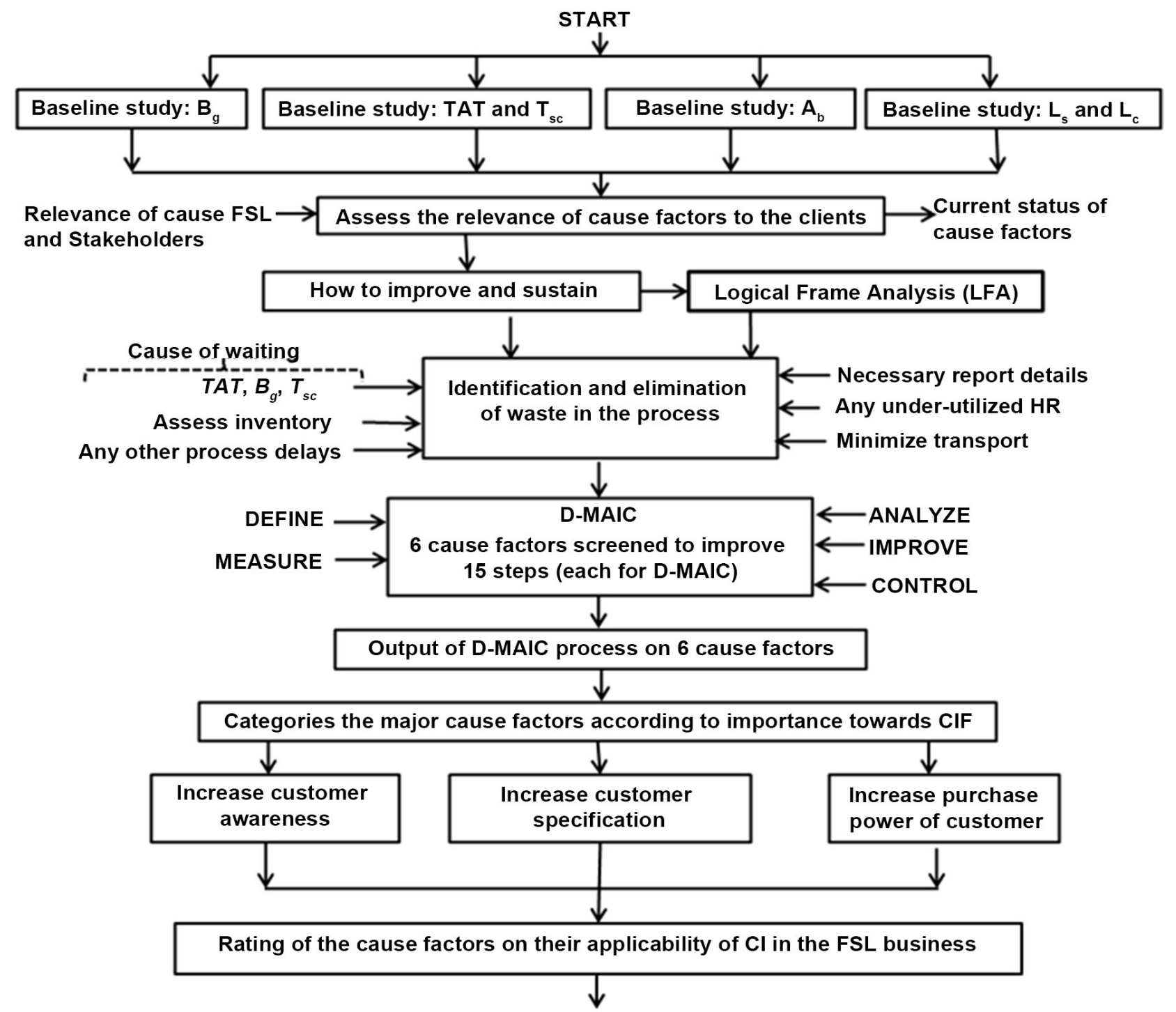

(a)

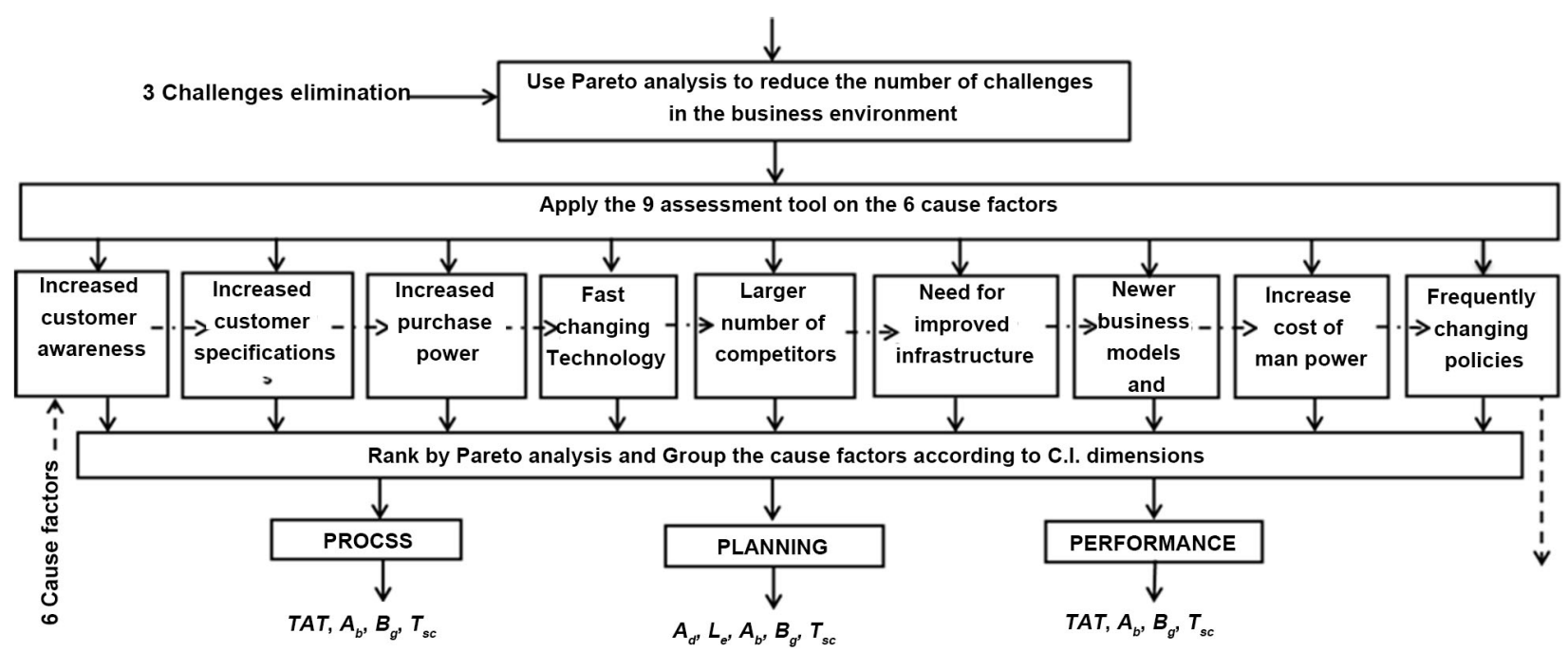

(b) 


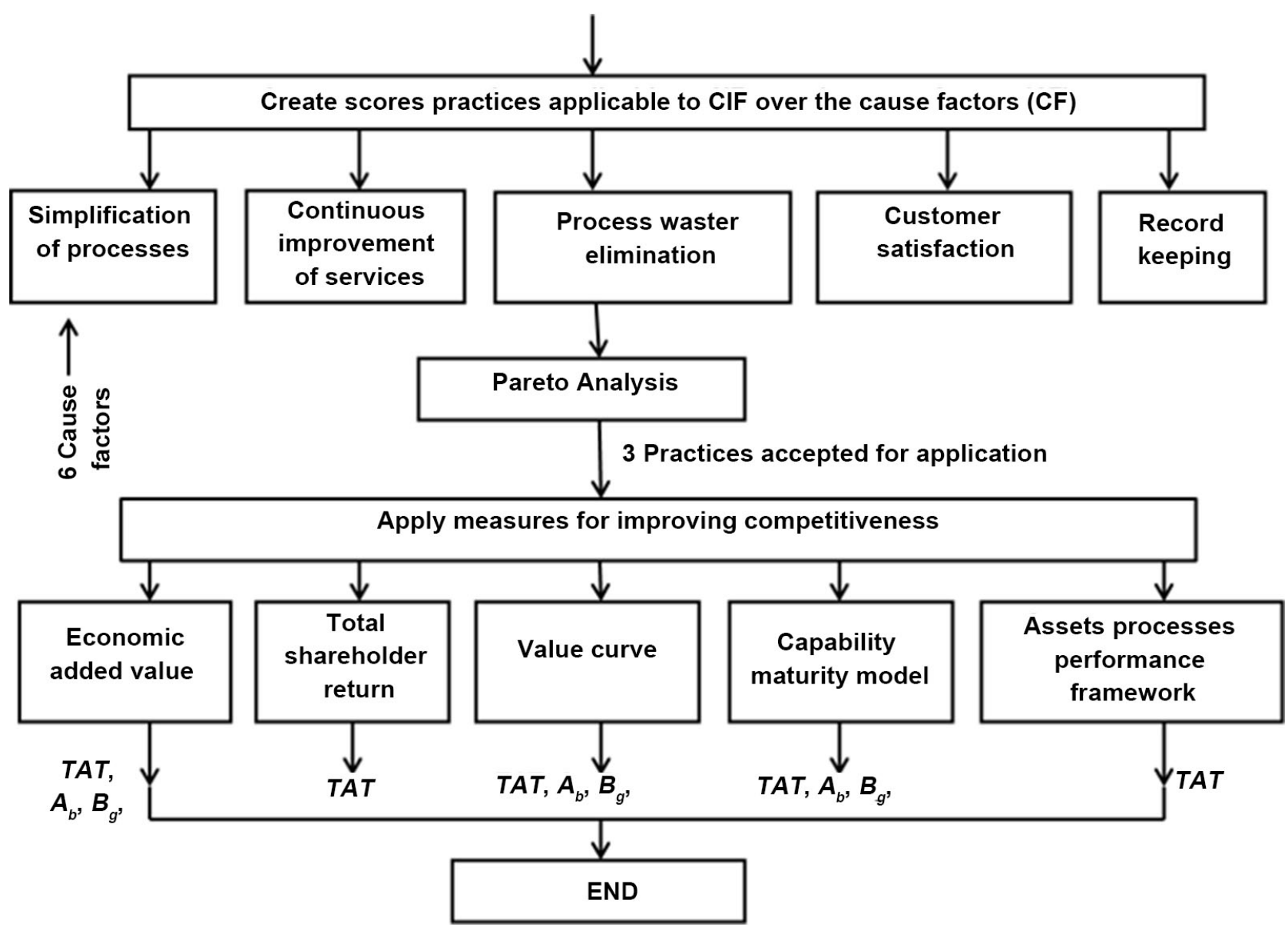

(c)

Figure 13. (a) Initial CIF development steps from baseline data collection to ranking of cause factors; (b) Prioritization of business environment challenges affecting the laboratory competitiveness using Pareto analysis; (c) Application of lean practices and economic measures for improving laboratory competitiveness.

perspectives and design analytical FSS strategies to reduce $T A T, T_{s c}$ and $B_{g}$. It also establishes a tool that will make complex FSL systems as simple as they need to be by structuring and prioritizing the workflow meanwhile reducing absenteeism. The CIF clarifies and creates focus thinking about complex relationships within FSS, thereby supporting communication across FSL disciplines, knowledge systems, and between forensic science and policy to increase staff longevity, professional and academic development.

\section{Conclusions}

The development of CIF based on captured variations in the laboratory processes including fluctuations in TAT between different case files, between different action points and different laboratory disciplines enabled a deep understanding of process variations, via statistical analysis (CDFs). While it is difficult to trace performance metrics in the laboratory due to difficulties in gathering data, this study shows that it is possible to capture data given well designed data collection tools. Variations in the backlogged case files with time revealed similar CDF 
shapes between different laboratory disciplines, but different nature of factors affecting case files inflow and reported or processed case files on weekly basis. The results show that the extent of backlogs is alarming necessitating action. The cause factors developed in this study were assessed for relevance to stakeholders, current status, means of improvements, low to sustain and future plans for sustainability.

The case factors studied were observed to be complex and interrelated based on dimensions of competitiveness (planning, process, and performance). A Venn diagram was used to represent the interrelationships between cause factors, followed by the need to establish the indicators of competitiveness, application of AHP methodology, improvement methods and sustainability analysis. The study reveals that competitiveness improvement requires managing the dimensions of competitiveness (performance, process, and planning). The study shows the process management areas such as customers of the process, relationship between customers, between quantity, schedule and cost, identifying process owners, performing improvements, and the role of measuring the current status. CIF development includes identification followed by elimination of wastes (such as waiting, overproduction, defects, under-utilized human resources, excess processing, transportation distances and inventory). The measured parameters were also assessed for importance and their effects to the FSL competitiveness, using Pareto analysis, for ranking business environment challenges (after detailed analysis) and ranking lean practices for improving FSL competitiveness.

The CIF development necessitated application of D-MAIC methodology based on simple 5-step and intensive 15-step methodology while providing relationship between each D-MAIC step with the cause factors and concepts used for conducting analysis of each step. The need for improving operational competitiveness involved linking the requirements with the cause factors. Some of the requirements utilized and linked to the cause factors include analysis of economic added value, total shareholder return, value curve, capability maturity model, and assets processes performance framework. This step involved also linking the categories of competitiveness paradigm with cause factors, analyzing forces that determine competitiveness, strategies to achieve better performance, and methods to improve operational competitiveness in relation to cause factors.

Finally, based on the developed methodology, the complete competitiveness improvement framework was presented in the form of a flowchart, showing the necessary steps with inputs to each step. The flow chart starts with data collection to establish the current situation for all six cause factors and ends with the final steps presenting the measures for improving the competitiveness.

\section{Acknowledgements}

The authors are grateful to the GCLA Management for financial support which enabled completion of this study. 


\section{Conflicts of Interest}

The authors declare no conflicts of interest regarding the publication of this paper.

\section{References}

[1] Warnack, M. (2003) Continual Improvement Programs and ISO 9001:2000. Quality Progress, 36, 42-49.

[2] Feist, A., Ashe, J., Lawrence, J., McPhee, D. and Wilson, R. (2007) Investigating and Detecting Recorded Offences of Rape. Home Office, London. https://doi.org/10.1037/e468392008-001

[3] Delisi, M., Hochstetler, A., Scherer, A.M., Purhmann, A. and Mark, B.T. (2008) The Stark Weather Syndrome: Exploring Criminal History Antecedents of Homicidal Crime Sprees. Criminal Justice Studies, 21, 37-47. https://doi.org/10.1080/14786010801972670

[4] Durose, M.R. (2008) Census of Publicly Funded Crime Forensic Crime Laboratories 2005. Bureau of Justice Statistics Bulletin. https://www.bjs.gov/content/pub/pdf/cpffcl09.pdf

[5] Omari, G.C., Manyele, S.V. and Mwaluko, G. (2017) Analysis of Stress Backlogs during Case-File Processing in Forensic Science Laboratory. Engineering, 9, 1060-1096. https://doi.org/10.4236/eng.2017.912063

[6] Coble, M.D. and Butler, J.M. (2005) Characterization of New MiniSTR Loci to Aid Analysis of Degraded DNA. Journal of Forensic Science, 50, 43-53. https://doi.org/10.1520/JFS2004216

[7] CCLRTF (2009) California Crime Laboratory Review Task Force Report.

[8] Bashinski, J. (2010) DNA Laboratory Monthly Statistics. Office of the Attorney General, California Department of Justice, Sacramento. http://ag.ca.gov/bfs/pdf/Monthly.pdf

[9] Hawkins, R.C. (2007) Laboratory Turnaround Time. Clinical Biochemist Reviews, 28, 179-194.

[10] Chung, H.-J., Lee, W., Chun, S., Park, H.-I. and Min, W.-K. (2009) Analysis of Turnaround Time by Subdividing Three Phases for Outpatient Chemistry Specimens. Annals of Clinical and Laboratory Sciences, 39, 144-149.

[11] Hilborne, L.H., Oye, R.K., McArdle, J.E., Repinski, J.A. and Rodgerson, D.O. (1989) Evaluation of Stat and Routine Turnaround Times as a Component of Laboratory Quality. American Journal of Clinical Pathology, 91, 331-335. https://doi.org/10.1093/ajcp/91.3.331

[12] Howanitz, P.J., Cembrowski, G.S. and Steindel, S.J. (1993) Physician Goals and Laboratory Test Turnaround Times. Archives of Pathology \& Laboratory Medicine, $117,22-28$.

[13] Steindel, S.J., Jones, B.A. and Howanitz, P.J. (1996) Timelineness of Automated Routine Laboratory Tests: A College of American Pathologists Q-Probes Study of 653 Institutions. Clinical Chimical Acta, 251, 25-40. https://doi.org/10.1016/0009-8981(96)06298-5

[14] Omari, G.C., Manyele, S.V. and Mwaluko, G. (2018) Analysis of Turnaround Time during Casefile and Sample Processing in Forensic Science Laboratory. Engineering, 10, 43-73. https://doi.org/10.4236/eng.2018.102005

[15] Steindel, S.J. (1995) Timeliness of Clinical Laboratory Tests, a Discussion Based on 
Five College of American Pathologist Q-Probe Studies. Archives of Pathology \& Laboratory Medicine, 119, 952-961.

[16] Kenagy, J.W., Berwick, D.M. and Shone, M.F. (1999) Service Quality in Healthcare. Journal of the American Medical Association, 281, 661-665. https://doi.org/10.1001/jama.281.7.661

[17] Rasasingham, R. (2015) The Risk and Protective Factors of School Absenteeism. Open Journal of Psychiatry, 5, 195-203. https://doi.org/10.4236/ojpsych.2015.52023

[18] Vanneste, Y.T.M., Mathijssen, J.J.P., Goor, L.A.M., van de Rots-de Vries, M.C. and Feron, F.J.M. (2015) Extensive Medical Absenteeism among Secondary School Students: An Observational Study on Their Health Condition from a Biopsychosocial Perspective. Open Journal of Preventive Medicine, 5, 111-121. https://doi.org/10.4236/ojpm.2015.53013

[19] Kanwal, N., Riaz, G., Riaz, M.S. and Safdar, S. (2017) Identify the Causes of Absenteeism in Nurses Mayo Hospital Lahore Pakistan. International Journaal of Social Sciecnce and Management, 4, 110-114. https://doi.org/10.3126/ijssm.v4i2.17171

[20] Goldberg, C.B. and Waldman, D. (2000) Modeling Employee Absenteeism: Testing Alternative Measures and Mediated Effects Based on Job Satisfaction. Journal of Organizational Behavior, 21, 665-676. https://doi.org/10.1002/1099-1379(200009)21:6<665::AID-JOB48>3.0.CO;2-P

[21] Chen, L.H. (2008) Job Satisfaction among Information System (IS) Personnel. Computers and Human Behavior, 24, 105-118. https://doi.org/10.1016/j.chb.2007.01.012

[22] Nyathi, M. (2008) Working Conditions That Contribute to Absenteeism among Nurses in a Provincial Hospital in the Limpopo Province. Curationis, 31, 28-37. https://doi.org/10.4102/curationis.v31i1.903

[23] Pillay, R. (2009) Work Satisfaction of Professional Nurses in South Africa: A Comparative Analysis of the Public and Private Sectors. Human Resource for Health, 7, 7-15. https://doi.org/10.1186/1478-4491-7-15

[24] Leszek, K., Zenon, M. and Michał, K. (2016) The Concept of Absenteeism Management System in a Company. The Małopolska School of Economics in Tarnów Research Study's Collection, 32, 59-73.

[25] Omari, G.C., Manyele, S.V. and Mwaluko, G. (2019a) Analysis of Measured Employees' Absenteeism in the Forensic Science Laboratory. Engineering, 11, 137-166. https://doi.org/10.4236/eng.2019.113012

[26] McHugh, M. (2001) Employee Absence: An Impediment to Organizational Health in Local Government. The International Journal of Public Sector Management, 14, 43-58. https://doi.org/10.1108/09513550110387066

[27] Onikoyi, I.A., Awolusi, O.D. and Ayodeji, B.M. (2015) Effect of Absenteeism on Corporate Performance: A Case Study of Cadbury Nigeria PLC, Ikeja, Lagos State, Nigeria. British Journal of Marketing Studies, 3, 58-71.

[28] Tiwari, U. (2014) Impact of Absenteeism and Labour Turnover on Organizational Performance at Iti, Nani Allahabad, India. Abhinav National Monthly Refereed Journal of Research in Commerce \& Management, 34, 9-15.

[29] Iles, P.A., Mabey, C. and Robertson, I.T. (1990) HRM Practices and Employee Commitment: Possibilities, Pitfalls and Paradoxes. British Journal of Management, 1 , 147-157. https://doi.org/10.1111/j.1467-8551.1990.tb00003.x

[30] Green, F. (1993) The Determinants of Training of Male and Female Employees in Britain. Oxford Bulletin of Economics and Statistic, 55, 103-122. https://doi.org/10.1111/j.1468-0084.1993.mp55001006.x 
[31] Mincer, J. (1997) The Production of Human Capital and the Life Cycle of Earnings: Variations on a Theme. Journal of Labor Economics, 15, 26-47. https://doi.org/10.1086/209855

[32] Nordhaug, O. (1998) Competencies Specificities in Organizations. International Studies of Management and Organisation, 28, 8-29. https://doi.org/10.1080/00208825.1998.11656725

[33] Robertson, M. and O’Malley-Hammersley, G. (2000) Knowledge Management Practices within a Knowledge-Intensive Firm: The Significance of the People Management Dimension. Journal of European Industrial Training, 24, 241-253. https://doi.org/10.1108/03090590010321205

[34] Garavan, T.N., Morely, M., Gunnigle, P. and Collins, E. (2001) Human Capital Accumulation: The Role of Human Resource Development. Journal of European In-dustrial Training, 25, 48-68. https://doi.org/10.1108/EUM0000000005437

[35] Hameed, A. and Waheed, A. (2011) Employee Development and Its Effect on Employee Performance: A Conceptual Framework. International Journal of Business and Social Science, 2, 224-229.

[36] Valles, A., Sanchez, J., Noriega, S. and Nuñez, B.G. (2009) Implementation of Six Sigma in a Manufacturing Process: A Case Study. International Journal of Industrial Engineering, 16, 171-181.

[37] Gijo, E.V., Scaria, J. and Antony, J. (2011) Application of Six Sigma Methodology to Reduce Defects of a Grinding Process. Quality and Reliability Engineering International, 27, 1221-1234. https://doi.org/10.1002/qre.1212

[38] Truchaud, A., Le Neel, T., Brochard, H., Malvaux, S., Moyo, M. and Cazaubiel, M. (1997) New Tools for Laboratory Design and Management. Clinical Chemistry, 43, 1709-1715.

[39] Kilgore, M.L., Steindel, S.J. and Smith, J.A. (1998) Evaluating Stat Testing Options in in Academic Health Center: Therapeutic Turnaround Time and Staff Satisfaction. Clinical Chemistry, 44, 1597-1603.

[40] Kaur, V., Kamaljit, S., Minni, V. and Chopra, B. (2015) Monitoring of Turnaround time (TAT) in Biochemistry Laboratory of a Tertiary Care Hospital in Punjab. Journal of Dental and Medical Sciences, 14, 9-12.

[41] Cooper, C.M., Ellram, L.M., Gardner, J.T. and Hanks, A.M. (1993) Meshing Multiple Alliances. Journal of Business Logistics, 18, 67-89.

[42] Mentzer, J.T., DeWitt, W., Keebler, J.S., Nix, N.W., Smith, C.D. and Zacharia, Z.G. (2001) Defining Supply Chain Management. Journal of Business Logistics, 22, 1-25. https://doi.org/10.1002/j.2158-1592.2001.tb00001.x

[43] Akhigbe, O.J. (2013) Human Resource Planning: A Key Factor in Ensuring the Effectiveness and Efficiency of Organization. Journal of Emerging Trends in Economics and Management Sciences, 4, 388-396.

[44] Omari, G.C., Manyele, S.V. and Mwaluko, G. (2019b) Analysis of Employee's Academic Development and Longevity in Forensic Science Laboratory. Engineering, 11, 206-230. https://doi.org/10.4236/eng.2019.114015

[45] Wernerfelt, B. (1984) A Resource-Based View of the Firm. Strategic Management Journal, 5, 171-180. https://doi.org/10.1002/smj.4250050207

[46] Collis, D.J. and Montgomery, C.A. (1995) Competing on Resources: Strategy in the 1990s. Harvard Business Review, 73, 118-128.

[47] Grant, R.M. (1991) The Resource-Based Approach to Strategy Analysis: Implications for Strategy Formulation. California Management Review, 33, 114-135. 
https://doi.org/10.2307/41166664

[48] Porter, M.E. (1998) Competitive Strategy: Techniques for Analyzing Industries and Competitors. University of Illinois-Urbana, Historical Research Reference in Entrepreneurial Ship, Free Press, New York.

[49] Morgan, G. (1986) Images of Organization. Sage, Newbury Park.

[50] Beamon, B.M. (1998) Supply Chain Design and Analysis: Models and Methods. International Journal of Production Economics, 55, 281-294. https://doi.org/10.1016/S0925-5273(98)00079-6

[51] Charan, P., Shankar, R. and Baisya, R.K. (2008) Analysis of Interactions among the Variables of Supply Chain Performance Measurement System Implementation. Business Process Management Journal, 14, 512-529. https://doi.org/10.1108/14637150810888055

[52] Taticchi, P., Tonelli, F. and Pasqualino, R. (2013) Performance Measurement of Sustainable Supply Chains: A Literature Review and a Research Agenda. International Journal of Productivity and Performance Management, 62, 782-804. https://doi.org/10.1108/IJPPM-03-2013-0037

[53] Gunasekaran, A., Patel, A. and Mcgaughey, R.E. (2004) A Framework for Supply Chain Performance Measurement. International Journal of Production Economics, 87, 333-347. https://doi.org/10.1016/j.ijpe.2003.08.003

[54] Bottani, E. and Montanari. R. (2010) Supply Chain Design and Cost Analysis Through Simulation. International Journal of Production Research, 48, 2859-2886. https://doi.org/10.1080/00207540902960299

[55] Murths, T.P. (1998) Country Capabilities and the Strategic State: How National Political Institutions Affect MNC Strategies. Strategic Management Journal, 15, 113-129. https://doi.org/10.1002/smj.4250151008

[56] Buclkey, P.J. (1998) The Limits of Explanations: Testing the Internalization Theory. Journal of International Business Studies, 19, 181-194. https://doi.org/10.1057/palgrave.jibs.8490382

[57] Bartlett, C. and Ghoshal, S. (1991) Global Strategic Management: Impact on the New Frontiers of Strategy Research. Strategic Management Journal, 12, 5-16. https://doi.org/10.1002/smj.4250120903

[58] Hamel, G. and Prahalad, C.K. (1989) Strategic Intent. Harvard Business Review, 67, 63-76

[59] Hammer, M. and Champy, J. (1993) Reengineering the Corporation: A Manifesto for Business Revolution. Scientific Research: An Academic Publisher, Harper Collins, New York. https://doi.org/10.1016/S0007-6813(05)80064-3

[60] D’Cruz, J.R. and Rugman, A.M. (1992) New Impact for Canadian Competitiveness. Faculty of Management, University of Toronto, Toronto.

[61] Bakan, İ. and Doğan, İ.F. (2012) Competitiveness of the Industries Based on the Porter's Diamond Model: An Empirical Study. International Journal of Research and Reviews in Applied Sciences, 11, 441-455.

[62] Bates, T. (1990) Entrepreneur Human Capital Inputs and Small Business Longevity. The Review of Economics and Statistics, 72, 551-559. https://doi.org/10.2307/2109594

[63] Qaiser, A., Tayyba, N., Imran, K., Rafaqet, A. and Asim, Y. (2018) The Impact of Human Resource Management Practices on Innovative Ability of Employees Moderated by Organizational Culture. International Journal of Organizational Leadership, 7, 426-439. https://doi.org/10.33844/ijol.2018.60434 
[64] Flood, C.R. and Michael, C.J. (1993) Critical Systems Thinking. Sage Journals: Organization Studies, 14, 613. https://doi.org/10.1177/017084069301400416

[65] Grant, J.L. (2003) Foundations of Economic Value Added. John Wiley and Sons, Hoboken.

[66] Sabol, A. and Sverer, F. (2017) A Review of the Economic Value Added Literature and Application. UTMS Journal of Economics, University of Tourism and Management, Skopje, 8, 19-27.

[67] Herciu, M. and Lucian, B. (2016) Creating Value-From Corporate Governance to Total Shareholders Return. An Overview. Studies in Business and Economics, 11, 36-50. https://doi.org/10.1515/sbe-2016-0019

[68] Hill, C.W.L. and Jones, G.R. (2010) Strategic Management Theory: An Integrated Approach, South-Western, USA.

[69] Kim, W.C. and Mauborgne, R. (1999) Creating New Market Space: A Systematic Approach to Value Innovation Can Help Companies Break Free from the Competitive Pack. Harvard Business Review, 83-93.

[70] Humphrey, W.S. (2002) Three Process Perspectives: Organizations, Teams, and People. Annals of Software Engineering, 4, 39-72. https://doi.org/10.1023/A:1020593305601

[71] Amaratunga, D., Baldry, D. and Sarshar, M. (2002) Assessment of Facilities Management Performance-What Next? Facilities, 18, 66-75. https://doi.org/10.1108/02632770010312187

[72] McDougall, G., Kelly, J., Hinks, J. and Bititci, U. (2002) A Review of the Leading Performance Measurement Tools for Assessing Buildings. Journal of Facilities Management, 1, 142-153. https://doi.org/10.1108/14725960310807881 